\title{
Microwave pyrolysis of lignocellulosic biomass--a contribution to power Africa
}

\author{
Saifuddin Nomanbhay ${ }^{*}$ (D), Bello Salman, Refal Hussain and Mei Yin Ong
}

\begin{abstract}
Worldwide efforts are being made to increase the use of renewable energy in order to reduce the emission of greenhouse gases. Africa is blessed with abundant resources of fossil fuels as well as renewable energy resources. Yet the continent, especially sub-Saharan Africa, is afflicted with power crisis. For example, in Nigeria, erratic electricity supplies will persist unless the government diversifies her energy sources and adopt new technologies available in the electricity generation sector. International Renewable Energy Agency (IRENA) has called for promotion of increased utilization of the continent's vast renewable energy resources to accelerate development. This review examines the perspective of renewable energy from biomass as an important strategy for a sustainable development in Nigeria. The paper also addresses the use of pyrolysis technology--an efficient thermo-chemical process for energy applications. However, the study presents on applications either to replace fossil fuel in an existing diesel engine-based power generation system or to generate electricity using a gas engine. The work also presented herein addresses the use of industrial- and non-industrial-derived biomass residues for energy purposes with specific example on solid palm oil residues in Nigeria. The current status of pyrolysis technology and its potential for commercial application for bio-fuel production using microwave-assisted pyrolysis in Nigeria are presented. This study will extensively review the recent work on microwave-assisted technology applied to the pyrolysis process. It is estimated that electrical power generation potential at about $500 \mathrm{MW}$ can be obtained by using only the available residues from oil palm industry in Nigeria. This potential can be increased 10-fold with more emphasis on expansion and modernization of oil palm industry in Nigeria. This will benefit in terms of higher revenue from the palm oil export as well as higher renewable energy generation from its biomass residue using the microwave-assisted pyrolysis technology.
\end{abstract}

Keywords: Nigeria, Bio-fuel, Bio-oil, Oil palm biomass, Microwave-assisted pyrolysis

\section{Review}

Energy consumption has been used as an index for measuring the development of a particular region, country, and economy. Population growth is one of the factors that cause explosive demand for energy use. Nigeria has the largest population in Africa, with a population of over 170 million and forecasted to grow to 310 million by 2035. Agriculture remains a large sector in many African economies, accounting for around $20 \%$ of regional GDP (compared with a 6\% share globally) and around $65 \%$ of employment [1]. Superimposed on this, the UN Population Division projects' future increases in the world's urban population are also expected to be highly concentrated in just a few countries depicted in Fig. 1.

\footnotetext{
* Correspondence: saifuddin@uniten.edu.my

Institute of Sustainable Energy, Universiti Tenaga Nasional (The National Energy University), Jalan IKRAM-UNITEN, 43000 Kajang, Selangor, Malaysia
}

Taken together, China, India, and Nigeria are projected to account for $37 \%$ of the increase of nearly 2.5 billion people in the urban population by 2050 . Between 2014 and 2050, the urban areas are expected to grow by 404 million people in India, 292 million in China, and 212 million in Nigeria. Similarly, at present, the largest rural populations in Africa are located in Nigeria (95 million), and between 2014 and 2050, it is expected to register the largest increase of 50 million [2].

Population is a major driver of energy demand and inadequate supply of energy constricts socio-economic activities, restricts economic growth, and adversely affects the quality of life. There is a correlation between electricity consumption and gross domestic product (GDP) of a nation. According to [3] sub-Saharan Africa has the highest population without electricity--about 640 million, rural electrification below par of $17 \%$ and yet, the 


\section{Contribution to the increase in urban population by country, 2014 to 2050 Population (million)
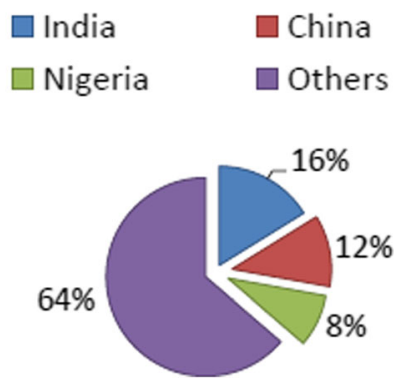

Fig. 1 Contribution to the increase in urban population by country 2014-2050. Adapted from [2]

region is known to have sufficient non-fossil and fossil energy resources largely unharnessed. The current energy production capacity has failed to support economic growth, infrastructural development, and in elevating living standards [4-6]. This makes many sub-Saharan Africa-based industries and manufacturing sectors uncompetitive and drags down annual GDP growth. For instance, [7] in their study on the relationship between energy consumption and economic growth in Nigeria covering periods 1980-2008 found that there was bidirectional causality between the two. To fulfill the economic and social growth of the region, the ability of government to develop the huge electricity capacity deficit is very crucial. The mission to widen access to modern energy services has been influential in shaping some of the discussions on energy at the international level. The year 2012 has been declared year of energy access and 2030 has been set as the year for achieving universal access to modern energy services. For the vast majority of African countries, lack of access to modern energy services constitutes a major obstacle in boosting industrial, agricultural, urban, and rural development. For many commercial enterprises, unreliable and costly supplies of electricity and modern fuels impede production, growth, and development.

Nigeria is richly blessed with primary energy resources. The country is endowed with large reserves of crude oil currently estimated to be about 36 billion barrels has an estimated amount of about 166 trillion standard cubic feet (5210 billion cubic meters). Nigeria holds the largest natural gas reserves on the continent and was the world's fourth largest exporter of liquefied natural gas (LNG) in 2015 [8]. Table 1 provides a brief summary of the significant primary energy resources in Nigeria [9].

The demand for electricity in Nigeria for 2016 is estimated to be around 12,800 MW; however, the available capacity is only around $4500 \mathrm{MW}--$ meets only one-third of the estimated demand [10]. The supply of electricity
Table 1 Nigeria's energy reserves and potentials (2005)

\begin{tabular}{llc}
\hline Resources type & Reserves & Reserves (BTOE) \\
\hline Crude oil & 36.0 billion barrels & 4.896 \\
Natural gas & 166 trillion SCF & 4.465 \\
Coal and lignite & 2.7 billion tonne & 1.882 \\
Tar sands & 31 billion barrel & 4.216 \\
Subtotal fossil & & 15.459
\end{tabular}

${ }^{\mathrm{a} B T O E}$ billion tonnes of oil equivalent. Adapted from [9]

${ }^{\text {bSCF }}$ standard cubic feet. Adapted from [9]

has been erratic with hydro and thermal routes being the major contributor of the electricity generation. Africa has the lowest level of electrification rate in the developing world at 25\%. In China, East Asia, and the Middle East, the electrification rate is around $91.8 \%$ compared to south Asia at $62.2 \%$ and Latin America at 93.4\% [11]. Average amount of electricity consumed per capita in Nigeria is $137 \mathrm{kWh}$, which is one of the lowest in the world [12]. Taking into account the desire to improve electrification, many African countries are putting great importance on power generation and distribution. Further to the shortage of power generation, transmission and distribution losses are also higher in Africa compared to the world average (11.3\% compared to 9.2\%). These losses exceed $20 \%$ in Senegal, Kenya, and Tanzania and $40 \%$ in Nigeria and Congo [13]. Despite the vast abundance of fossil fuels (oil and gas), the fossil fuels have only contributed $18.1 \%$ to the total primary energy consumption in Nigeria $[12,14]$. The greater portion of the crude oil produced in the country is usually exported. In 2007 , more than $98 \%$ of the crude oil extracted in the country was exported, leaving less than $2 \%$ for local consumption [12]. Despite the ample coal, oil, and natural gas reserves, at the present rate of extraction, it has been estimated that these reserves, by the next 40 years, will be depleted to a point uneconomical to continue exploration. It therefore becomes imperative that alternative sources of energy are explored.

When it comes to electrification, choosing the right technology available among the various technological alternatives is important. Both off-grid and on-grid options are normally promoted in parallel when pursuing rural electrification in many developing countries [15]. Sustainability is one of the key concerns in terms of energy access. Sustainable development is development that meets the needs of the present, without compromising the ability of future generations to meet their own needs. The Intergovernmental Panel on Climate Change [16] states that currently, energy-related greenhouse gas (GHG) emissions, mainly from fossil fuel combustion for heat supply, electricity generation, and transport, account for around $70 \%$ of total emissions including carbon dioxide, methane, and some traces of nitrous oxide. It is crucial to implement greenhouse gas 
(GHG) emission reduction technologies for fossil fuel combustion processes. Strategies for climate change mitigation are necessary on a global scale, particularly for high GHG emitters like the industrialized countries, countries in transition, and rapidly developing countries. It is vital that new energy demands are met, where possible, by sustainable and non-polluting means, in order to stop the escalation of the environmental effects of fossil fuel use. Furthermore, to meet emissions targets and reduce the environmental threat, current reliance on fossil fuels for all energy uses must be reduced drastically. Consequently, it will be necessary to re-evaluate the way in which energy is produced, distributed, and used worldwide. This, however, will not happen until less expensive, easily implemented, and equally reliable alternatives become available. To achieve the necessary reduction in fossil fuel use, a number of measures can be considered.

- The electricity supply grid can be supplied with an increasing amount of electricity generated from sustainable and non-polluting sources.

- The use of waste and biomass, or fuels derived from these, can be considered for transportation, heating and cooking, electricity production, and energy storage.

- The use of combined heat and power (CHP), where the waste heat from electricity production is used for space and water heating or cooling (increasing fuel utilization often by a factor of two or more).

- Due to the availability of efficient small scale renewable energy generating plant, it can be worthwhile to consider on-site electricity generation for own use, especially where there are exploitable local resources (biomass or waste fuel, and/or a local wind or solar resource).

In its Special Report on Renewable Energy Sources and Climate Change Mitigation [17], the IPCC draws the conclusion that renewable energy sources can play an important role in this transformation process. The urgent energy situation requires the current existing energy system to undertake both fundamental reforms by shifting to other energy resources and gradual improvements by adopting more advanced technologies for energy generation and production. A shift of primary energy resources from fossil fuels to renewable energy could greatly reduce the current heavy dependence upon fossil fuels. Renewable energy sources can be highly transient and exhibit strong short-term and seasonal variations in their energy outputs. Their variability poses problems for applications that require a continuous supply of energy [18]. In addition, renewable resources typically have a low energy density, often large collection areas are required to generate modest power outputs. It has been projected that the production of liquid fuels from biomass will soar in the next 30 years irrespective of whether the oil prices are low or high; thus, new technologies must be developed for the efficient conversion of biomass to fuels that have high energy density and compatibility with the existing energy infrastructure [19]. Two significant barriers impede widespread deployment of renewable energy, cost, and demand side servicing. While cost is an important factor, the variability related to the inherent temporal mismatch between resource availability (sun shining, wind blowing etc.) and the load poses a serious technical issue for the deployment of renewable energy. Power from these resources may not be available when required. For renewables to assume a role as a primary energy source, the availability issue must be addressed. One commonly quoted solution is to incorporate a broad mix of renewable sources. Countries like Denmark which have lead the way in incorporating renewable energy into their energy system have published energy plans which target $50 \%$ renewable by 2030 and $100 \%$ by 2050 [20]. Currently, wind and solar power are assumed to be the key technologies in this development. However, their production fluctuates greatly over time (depending on changing weather patterns) and sites with high potential are often some distance from demand centers like cities. Lignocellulosic and other forms of biomass are some of the main renewable energy resources available and considered as promising alternative to provide the source of renewable liquid, gaseous, and solid fuels. It is the oldest source of energy used by humans, and it is able to supply all kinds of fuels, chemicals, and materials, which we currently obtain from petroleum, coal, or natural gas. The purpose of such review is to highlight the importance of renewable energy derived from biomass in complementing the present government of Nigeria's effort to address the nations over dependence on its fossil fuels for federal revenues and energy mix.

\section{Renewable energy potentials in Nigeria}

Access to reliable, efficient, affordable, and environmentfriendly modern energy services for basic needs is necessary for human development and sustainable economic growth. Though it is the fastest growing form of energy, renewable energy (RE) contributes just around 3\% of the global energy supply [8]. Energy is one of the main factors that must be considered in the discussions of sustainable development. Current and future possible environmental, economic, political, and social consequences have force the countries to incline towards to renewable energy resources. Choice of the appropriate solution to be applied within energy sector is a complicated problem: great number of alternatives and criteria must be evaluated paying attention to the social, economic, technological, and 
environmental factors [21]. The basic premise of all renewable energy development policies is that they create demand for climate-friendly technologies that otherwise would not exist at all or not at desired levels under current market conditions [22]. Determining the appropriate energy policy problem can be viewed as a Multiple Criteria Decision-Making (MCDM) problem. A comprehensive list of evaluation criteria and indicators used in MCDM studies conducted on energy issues used by researches is presented in Table 2, where the sustainability aspects are grouped in technical, economic, environmental, and social criteria [23].

The AHP (Analytical Hierarchy Process) methodology (which is a multi-criteria decision-making) method developed by [24] has been used by other researchers to make a multi-criteria selection among alternative renewable energy options [23, 25-28]. AHP is effective in dealing with complex decision-making because it reduces complex decisions to a series of pairwise comparisons. It generates a weight for each evaluation criterion and scenario according to the information provided. The AHP combines the objective and scenario evaluations to determine a relative ranking of the scenarios. In one particular study using AHP to evaluate the best renewable energy technology, [25] reported that the multi-criteria decision analyses showed that the wind energy is the best renewable energy alternative. The ranking of the other alternatives in descending order were biomass, geothermal, solar, and hydropower. Also, the evaluation of criteria indicated that environmental effects are more important in this problem of technology selection. Renewable energy has considerable potential in Nigeria and could bridge the major energy gaps in rural areas, particularly northern Nigeria.

Nigeria is greatly endowed with sufficient renewable energy resources to suffice its present and future development requirements. Renewable energy provides a safe and feasible option for the provision of a clean and environment-friendly energy. The huge potential for renewable energies is largely untapped in Nigeria. There have been various explorations of renewable energy in Nigeria since 1990s. Renewable energy supply in Nigeria

Table 2 Selection criteria for sustainable energy planning. From [23]

\begin{tabular}{ll}
\hline Criteria & Indicators \\
\hline Technical & $\begin{array}{l}\text { Efficiency, exergy efficiency, primary energy ratio, safety, } \\
\text { reliability, maturity. }\end{array}$ \\
Economical & $\begin{array}{l}\text { Investment cost, operation and maintenance cost, fuel } \\
\text { cost, electric cost, net present value, payback period, } \\
\text { service life, equivalent annual cost. }\end{array}$ \\
Environmental & $\begin{array}{l}\text { NOx emission, } \mathrm{CO}_{2} \text { emission, } \mathrm{CO} \text { emission, } \mathrm{SO}_{2} \text { emission, } \\
\text { particles emission, non-methane volatile organic } \\
\text { compounds, land use, noise. }\end{array}$ \\
Social & Social acceptability, job creation, social benefits. \\
\hline
\end{tabular}

is dominated by hydropower and solar energy. Quite a number of literature have reported the RE potentials in Nigeria as illustrated in Table 3.

These REs could potentially facilitate in overcoming the energy supply deficit and also decrease emission level and improved living standard of the Nigeria people.

Solar energy potential is enormous in Nigeria, with fairly evenly distributed solar radiation averaging $19.8 \mathrm{MJ} / \mathrm{m}^{2} / \mathrm{day}^{-1}$ and an average of $6 \mathrm{~h}$ of sunshine a day; ranging between about $3.5 \mathrm{~h}$ at the coastal areas and $9.0 \mathrm{~h}$ at the far northern border areas [29]. The country is also characterized with some cold and dusty atmospheric conditions during the Harmattan season, in its northern part, for a period of about 4 months (November-February) annually. The assumed potential for concentrated solar power and photovoltaic generation is around 427,000 MW [30].

Hydropower has been the very important for the gridpowered generation in Nigeria for decades. The country is reasonably endowed with large rivers and a few natural waterfalls. It is the second largest type of renewable energy available in Nigeria [14]. The total potential of hydropower in Nigeria is about 14,750 MW. However, only $1930 \mathrm{MW}(14 \%)$ of that potential is currently being generated, which represent about $30 \%$ of gross installed grid-connected electricity generation capacity of Nigeria [14]. Small hydropower (SHP) has gained rapid consideration; this is due to its inherent advantages such as reduce cost and maintenance. Based on the 1980 survey, $734 \mathrm{MW}$ of SHP can be harnessed from 277 sites, the potential of the SHP is estimated at $3500 \mathrm{MW}$, representing $23 \%$ of the Nigeria's total hydropower potential [30, 31].

Wind energy potential is very modest, with annual average speeds of about $2.0 \mathrm{~m} / \mathrm{s}$ in the coastal region and $4.0 \mathrm{~m} / \mathrm{s}$ at heights of $30 \mathrm{~m}$ in the far north of the

Table 3 Renewable energy potentials in Nigeria--source [109]

\begin{tabular}{|c|c|c|}
\hline Resource & Potential & Current utilizations \\
\hline \multirow[t]{5}{*}{ Biomass } & $\begin{array}{l}\text { Agricultural } \\
\text { residues }\end{array}$ & 91.4 million tons/year produced \\
\hline & Animal wastes & 245 million assorted animals in 2001 \\
\hline & Energy crops & $\begin{array}{l}28.2 \text { million hectares of arable land; } \\
8.5 \text { cultivated }\end{array}$ \\
\hline & Fuel wood & 43.4 million tons/year consumption \\
\hline & Municipal waste & $\begin{array}{l}18.5 \text { million tons produced in } 2005 \text { and } \\
\text { now estimated at } 0.5 \mathrm{~kg} / \mathrm{capita} / \text { day }\end{array}$ \\
\hline $\begin{array}{l}\text { Large } \\
\text { hydropower }\end{array}$ & $11,250 \mathrm{MW}$ & $1900 \mathrm{MW}$ \\
\hline $\begin{array}{l}\text { Small } \\
\text { hydropower }\end{array}$ & $3500 \mathrm{MW}$ & $64.2 \mathrm{MW}$ \\
\hline Solar & $\begin{array}{l}\text { 4.0-6.5 } \mathrm{kWh} / \mathrm{m}^{2} / \\
\text { day }\end{array}$ & $\begin{array}{l}15 \mathrm{MW} \text { dispersed solar PV installations } \\
\text { (estimated) }\end{array}$ \\
\hline Wind & $\begin{array}{l}2-4 \mathrm{~m} / \mathrm{s} @ 10 \mathrm{~m} \\
\text { height mainland }\end{array}$ & $\begin{array}{l}\text { Electronic wind information system } \\
\text { (WIS) available }\end{array}$ \\
\hline
\end{tabular}


country [32]. With an air density of $1.1 \mathrm{~kg} / \mathrm{m}^{3}$, the wind energy intensity perpendicular to the wind directions ranges between $4.4 \mathrm{~W} / \mathrm{m}$ at the coastal areas and $53.2 \mathrm{~W} / \mathrm{m}$ at the far northern region of Nigeria [33]. At present, the share of wind energy in the national energy consumption has remained very low with no wind power plants connected to the national grid.

Geothermal energy is a thermal energy generated and stored in the earth interior. Geothermal energy resource consists of thermal energy from the earth's interior stored in hot dry rocks as well as rocks with trapped steam or liquid water. In Nigeria, the geothermal energy is not well exploit. Currently, there are two Known Geothermal Resources Areas (KGRAs) in Nigeria; the Ikogosi warm springs of Ondo state and the Wikki warm springs of Bauchi state [34].

Biomass fuels as renewable energy sources have increasingly been considered as a key option to substitute conventional fossil fuels. Conversion of biomass into renewable motor fuels, together with the associated environmental and geopolitical benefits, has driven considerable research in the area. The term biomass is commonly identified as biological material from living plant or dead plant. In the present context, biomass refers to dead trees, branches and tree stumps, yard clippings, off-cuts, wood chips, and agro residues. Biomass is considered as one of the renewable energy sources with the highest potential to contribute to the energy needs of modern society for both the industrialized and developing countries. While biomass is being used for cooking and heat, it is currently not being fully used to produce electricity in Nigeria $[35,36]$.

\section{Lignocellulosic biomass and energy potential}

The intermittency of renewable power sources such as wind and photovoltaic (PV) presents a major obstacle to their extensive penetration into the grid [18]. The quest for renewable sustainable energy sources has given biomass a prominence it had lost during the industrial revolution after the discovery of convenient fossil fuels like coal and oil. Biomass defined by the United Nations Framework Convention on Climate Change (UNFCCC 2005)--"Is a non-fossilized and biodegradable organic material originating from plants, animals and microorganisms. This shall also include products, by-products, residues and waste from agriculture, forestry and related industries as well as the non-fossilized and biodegradable organic fractions of industrial and municipal wastes." On a comparative basis, biomass is considered carbonneutral, meaning there is no addition to the $\mathrm{CO}_{2}$ inventory by the burning of biomass, which is also worthy to clarify against cutting trees for energy supply because they serve as a $\mathrm{CO}_{2}$ sink. A tree stops absorbing $\mathrm{CO}_{2}$ after it stops growing or dies. Similarly, if left alone on the forest floor, it can release $\mathrm{CO}_{2}$ through natural degradation or in a forest fire and even incomplete combustion as the case for household and cottage usage. Furthermore, a dead tree could release more harmful $\mathrm{CH}_{4}$ if left to decompose in water [37]. Biomass comes in a variety of forms, which can be utilized as an energy resource. Loosely, biomass may also be classified into two broad groups: Virgin biomass includes lignocellulose (wood, plants, and leaves) and carbohydrates (crops and vegetables) and Waste biomass comprises municipal solid waste (solid and liquid wastes); sewage, animal, and human wastes; gases derived from landfilling (mainly methane); and agricultural wastes. Nigeria have in excess both types of biomass mentioned above; however, the present state of the Nigerian agricultural sector is overwhelmingly a small or medium scale production. The producers are not relishing the full scale production capacity and enhanced productivity because of the lack of basic amenities, finance, modern agricultural technology, and modern downstream processing technology.

Lignocellulosic materials including agricultural wastes, forestry residues, grasses, and woody materials have great potential for bio-fuel production. Typically, most of the agricultural lignocellulosic biomass is comprised of about $10-25 \%$ lignin, $20-30 \%$ hemicellulose, and $40-50 \%$ cellulose [38]. Cellulose is a major structural component of plant cell walls, which is responsible for mechanical strength and chemical stability to plants. Cellulose is a linear crystalline polysaccharide, with general formula $\left(\mathrm{C}_{6} \mathrm{H}_{10} \mathrm{O}_{5}\right) n$. The polymer is formed from repeating units of cellobiose, a disaccharide of $\beta$-linked glucose moieties. The hemicellulose macromolecules are often repeated polymers of pentoses (including xylose and arabinose) and hexoses (including galactose, glucose, and mannose). Unlike cellulose, the composition of hemicelluloses and lignin is heterogeneous and can vary greatly even within a given biomass species. Hemicelluloses have an amorphous structure and display branching in their polymer chains [39]. Lignin which comprises from $20-30 \%$ of the wood is the cementing agent which binds the individual wood fibers together to form a substance of strength and rigidity. The lignins are highly branched, substituted, mononuclear polymers of phenylpropane units. The main components of plant biomass are shown in Fig. 2. Currently, more focus is given on non-food crops (lignocellulosic) biomass. Presented in Table 4 are estimate of residues from selected agricultural crops in Nigeria for 2010 and the total energy available for each crop residue [11]. Who explored agro residues and power generation potential in sub-Saharan Africa, suggested that Nigeria has the highest agro residue production of 22.783 million tons in the continent. Based on the projection for oil palm residue with estimated total energy of about 44 PJ/year in 2010 for Nigeria, as shown in Table 4; an estimated $450 \mathrm{MW}$ of electricity generation potential can be realized assuming an efficiency of $30 \%$ for 


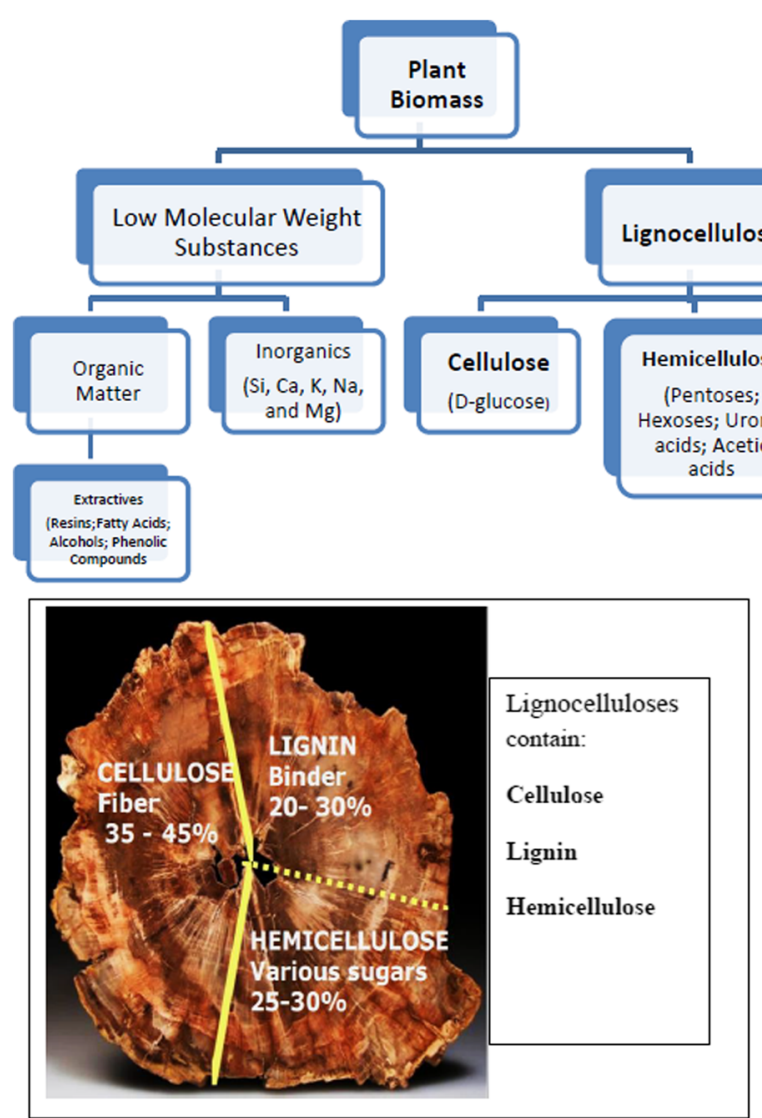

Fig. 2 Composition of the plant biomass (adapted from [93])

power plants ( $250 \mathrm{~kW}$ and above type). Various studies in the literature [36, 40-42] have been instrumental in identifying a number of bio-fuel scenarios using different feedstocks in Nigeria. Another source of biomass may comprise of Municipal and Animal Solid Waste. Similarly, it has been estimated that Nigeria produces about 227,500 tons of fresh animal waste daily sufficient to generate $12,400-17,400 \mathrm{GWh}$ of electricity year on year [7, 43].

Biomass can be used in a variety of ways to provide energy [44]:

- By direct combustion to provide heat for use in heating, for steam production, and hence, electricity generation.

- By gasification to provide a fuel gas for combustion for heat, or in an engine or turbine for electricity generation.

- By pyrolysis to provide a liquid fuel that can substitute for fuel oil in any static heating or electricity generation application.

Among various renewable energy resources, biomassbased power generation systems can provide grid quality steady power [11]. It has been proposed that "bioenergy" (energy from biomass and waste) has the highest contribution among all renewable materials towards reducing a country's carbon footprint and also fossil fuel dependence [45]. The use of biomass as fuel in substitution of fossil resources results in low sulfur dioxide emissions and almost no net atmospheric carbon emissions, and hence serves to mitigate greenhouse gas and global climate change impacts. Biomass-based power plants operating throughout the year with plant load factors in excess of $70 \%$ are conceivable and this would make their performance comparable to centralized power stations [46]. The possible contribution of biomass to future global energy supply ranges from below $100 \mathrm{EJ} /$ year to over $400 \mathrm{EJ} /$ year by 2050 . As a matter of comparison, the global energy demand in 2010 reached 12,380 Mtoe in 2010, equivalent to 518 EJ [47]. However, the current use of renewable sources for energy production is limited to an extent, which is considerably lower than their potential. This is mainly due to relatively high costs of the technologies for biofuel production from biomass. Modernized bioenergy systems are suggested to be important contributors to future sustainable energy systems and to sustainable development in industrialized countries as well as in developing countries like Nigeria. 
Table 4 Residues estimate from agricultural crops, 2010--source [109]

\begin{tabular}{|c|c|c|c|c|c|}
\hline Crop & Component & Production area (000 ha) & Production (000 ton) & Amount available million tons & Total energy available (PJ) \\
\hline \multirow[t]{2}{*}{ Rice } & Straw & 4473.00 & 3368.24 & 7.86 & 125.92 \\
\hline & Husk & & & 1.19 & 23 \\
\hline \multirow[t]{3}{*}{ Maize } & Stalk & 7677.00 & 7676.85 & 10.75 & 211.35 \\
\hline & Cob & & & 2.10 & 34.19 \\
\hline & Husk & & & 0.92 & 14.32 \\
\hline \multirow[t]{2}{*}{ Cassava } & Stalk & $42,533.00$ & $42,533.17$ & 17.01 & 297.68 \\
\hline & Peelings & & & 76.56 & 812.3 \\
\hline \multirow[t]{2}{*}{ Groundnut } & Shells & 3799.00 & 3799.25 & 1.81 & 28.35 \\
\hline & Straw & & & 4.37 & 76.83 \\
\hline \multirow[t]{2}{*}{ Soybean } & Straw & 356.00 & 365.06 & 0.91 & 11.27 \\
\hline & Pods & & & 0.37 & 4.58 \\
\hline \multirow[t]{2}{*}{ Sugarcane } & Baggasse & 481.00 & 481.51 & 0.11 & 1.99 \\
\hline & Tops/leaves & & & 0.14 & 2.21 \\
\hline Cotton & Stalk & 602.00 & 602.44 & 2.25 & 41.87 \\
\hline Millet & Straw & 5171.00 & 5170.45 & 7.24 & 89.63 \\
\hline Sorghum & Straw & 7141.00 & 7140.96 & 7.14 & 88.39 \\
\hline Cowpea & Shells & 2860.00 & 3368.24 & 4.89 & 95.06 \\
\hline \multirow[t]{3}{*}{ Oil Palm } & Fiber & 3200.00 & 8500.00 & 1.02 & 11.57 \\
\hline & Empty fruit bunch & & & 1.96 & 15.95 \\
\hline & Palm Kernel & & & 0.88 & 16.53 \\
\hline
\end{tabular}

Most of the studies consider biomass plantations as the most important source of biomass for energy (e.g., biomass plantation supply is forecast to be between 47 and $238 \mathrm{EJ} /$ year by the year 2050) [48]. [Note: 1 million tons of oil equivalent (Mtoe) $=4.2 \times 10^{16} \mathrm{~J}$ and $1 \mathrm{EJ}=$ 23.9 Mtoe]. For a case in point and in the context of the Malaysian oil palm industry, which has become a key economic growth driver for the country with 4.69 million hectares of planted land, 416 mills, 50 refineries, and 17 Oleochemicals plants, garnered RM52.7 (US\$13.5) billion in Gross National Income (GNI) in 2014 [49]. Unquestionably, by emulating the success of the Malaysia oil palm industry, there can be of tremendous opportunities in supplying renewable energy and developmental growth in Nigeria via the agricultural waste biomass. Nigeria has significant potential to produce biofuels and even become an international supplier [36]. Some researchers, while firmly advocating the use of solar PV, also suggest other sources of power using agriculture and municipal waste to generate biofuel must be undertaken aggressively [50].

\section{Oil palm biomass and palm oil production residues}

The oil palm (Elaeis guineensis) could be the best choice among the various plant biomasses for renewable energy production due to the intensive development in palm-oil production during the last decade. Oil palm is the most efficient oilseed crop in the world. One hectare of oil palm plantation is able to produce up to eight times more oil than other leading oilseed crops as shown in Fig. 3 [51]. The efficiency of its production (4000 kg/ha), low cost, and stability of the oil makes it the most attractive and widely used vegetable oil in the world [51]. Palm oil is ubiquitous in global products, including food, cosmetics, detergents, plastics, industrial chemicals, and biofuels. The global demand of palm oil is continuously growing, and thus, the production worldwide is also increasing as shown in Fig. 4 [52]. Indonesia and Malaysia produce over $80 \%$ of the world's palm oil. Other producer countries include Thailand, Columbia, Nigeria, Papua New Guinea, and Ecuador. This increase has been favored due to the high yield and versatility of palm oil

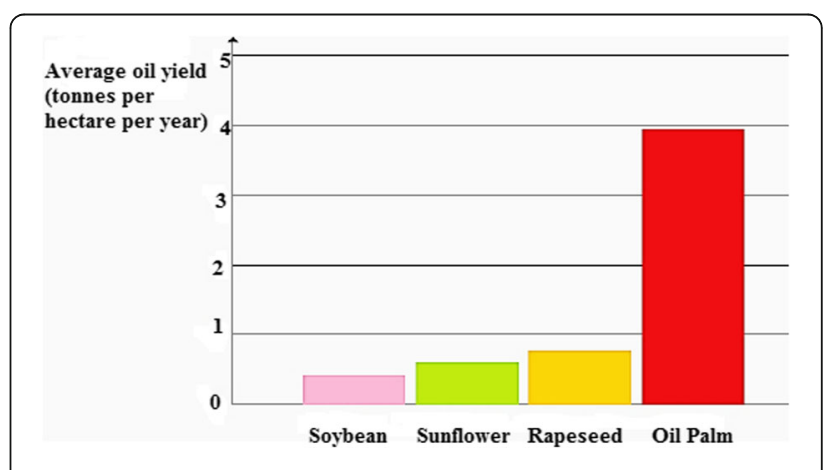

Fig. 3 Oil palm production efficiency compared to other major oil crops 


\section{PALM OIL WORLD PRODUCTION}

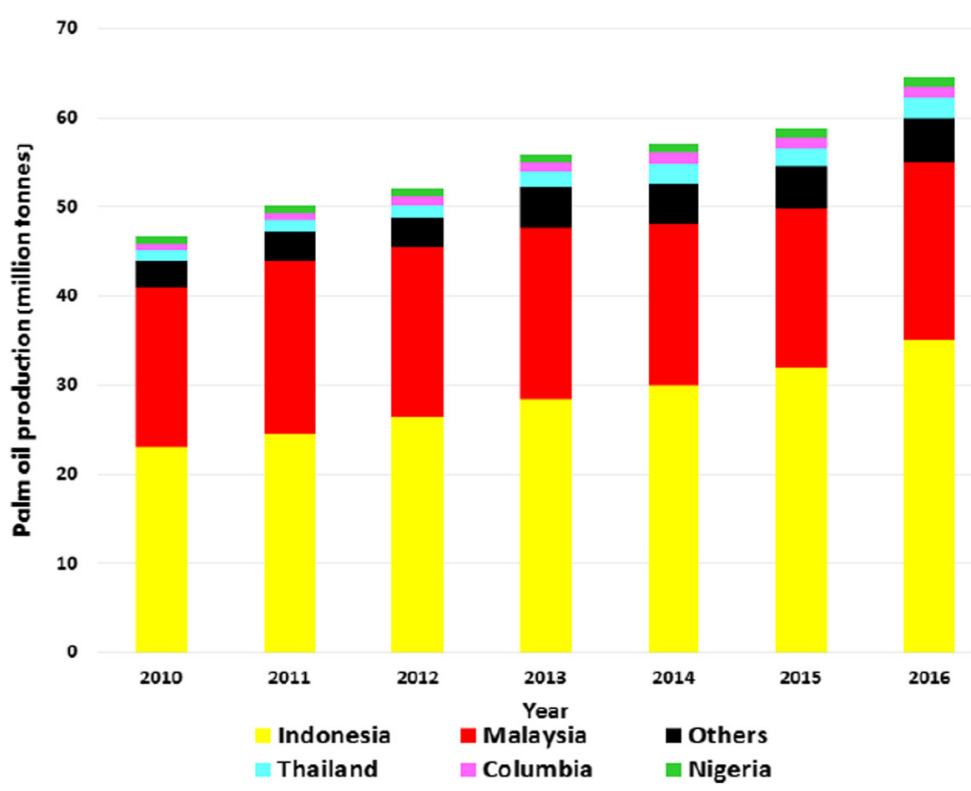

Fig. 4 Global palm oil production, 2010-2016, not including palm kernel oil (data source from [53])

which is suitable for edible and non-edible applications. Palm oil is being increasingly used for non-food purposes. In 2000, when production was 24.3 million tonne, 3.5 million tonne (15\%) was used for industrial purposes. In 2010, production rose to almost 46 million tonne and 14 million tonne was used for industrial purposes [53, 54]. The industrial usage will further increase when palm biodiesel is widely used as biofuel especially in European countries and US. Without the large volume of palm oil, there would be a major problem in meeting world demand for vegetable oil. As global demand increases and available land becomes increasingly scarce in the traditional production countries, governments of developing and emerging countries such as Brazil, Peru, and Central and Western Africa are increasingly promoting oil palm cultivation as a major contributor to poverty alleviation, food, and energy independence [55-57].

Palm oil industry generates a huge quantity of residues which can be processed to produce biofuel. Generally, an oil palm tree starts to bear fruit after 3-4 years. The palm fruit is oval (Fig. 5) and weights up to $30 \mathrm{~g}$; it grows in bunches with up to 1500 fruits with a total weight of $20-30 \mathrm{~kg}$. After harvesting, the oil palm fruits are transported quickly to the palm oil mill to be processed into palm oil. Two distinct types of vegetable oil can be produced from oil palm fruit--crude palm oil (CPO) which is produced from the mesocarp and palm kernel oil which is produced from the kernel or endosperm. The extracted oil constitutes only $10 \%$ of the total biomass generated while the other $90 \%$ is considered as wastes. With ever growing palm oil industry, amount of residues generated will escalate, adding complexity to the current waste management procedures. On average, 50-70 tonnes of biomass residues are produced from each hectare of oil palm plantation [58]. The by-products or wastes generated from palm oil production includes oil palm trunk (OPT), oil palm frond (OPF), empty fruit bunch (EFB), mesocarp fruit fiber (MF), palm kernel shells (PKS), and palm oil mill effluent (POME) [59]. Except POME, these wastes have high fiber content. Figure 6 shows a typical palm oil production process in Malaysia.

The palm oil mill plant is generally energy self-sufficient processing plant. Currently, relatively low efficient boilers are installed in mills to produce steam for sterilization, drying, and power generation. The wastes generated during the oil production process, mainly EFB, MF, and PKS are generally burnt as fuel in mill boilers to generate steam or hot gas for drying, sterilization, and power generation. The OPT and OPF generated during the replanting

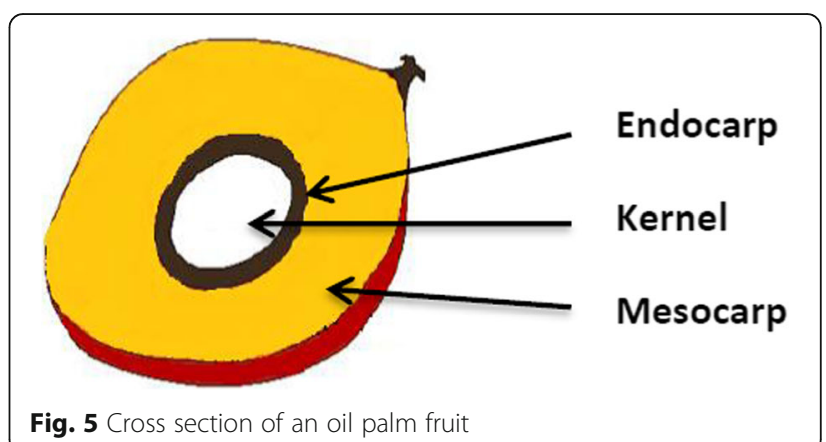




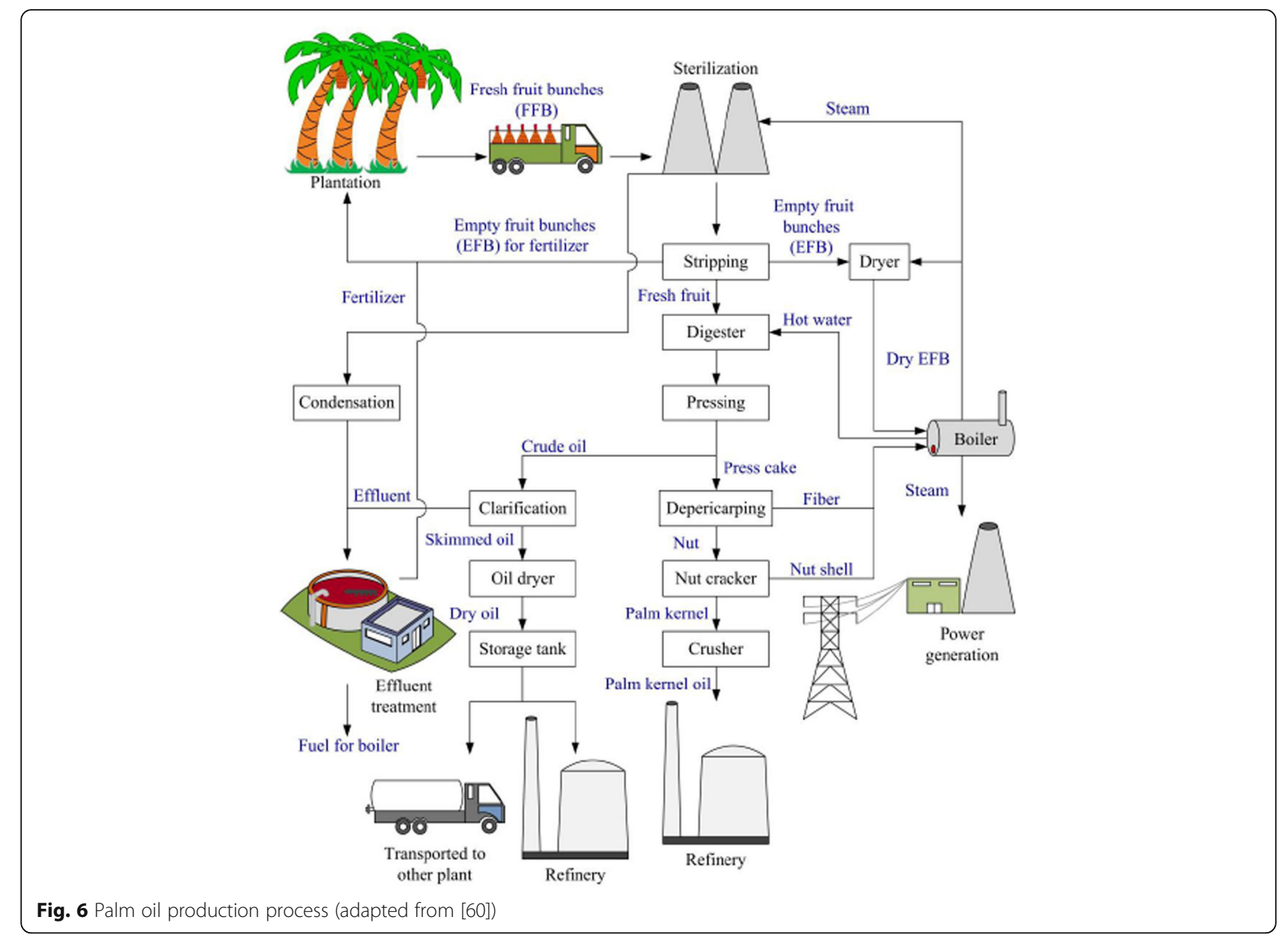

session can be problematic as the current method of leaving the dead tress between the rows of palm trees to naturally decompose for soil conservation, erosion control, and in the long-term nutrients recycling purpose; poses the risk of attracting harmful insect. The other method is to utilize them as soil fertilizer by burning. This will minimize the risk of attracting insects; however, it results in air pollution. A more efficient and environmentfriendly utilization of the generated OPT and OPF during the replanting session is urgently needed. On the one hand, the success of the palm oil industry has generated economic benefits including poverty alleviation; however, it has received intense negative reviews. The fast expansion of oil palm plantations has raised issues about the industry sustainability and its impact on the environment [60]. In the current waste management scenario for the palm oil industry, the biomass residues generated are underutilized. Therefore, there is a need to explore and evaluate various strategies to maximize the utilization of these biomass wastes produced in the plantations and mills to meet energy demands. This will reduce the cost of waste treatment and increase the profitability through the energy generated [60, 61].
Bioenergy from solid biomass residues of oil palm Biomass is an important energy source to create a more sustainable society. Generally, there is large diversity of the biomass in nature. The composition and properties of biomass need to be improved to enable their application as sustainable fuel in highly efficient biomass to energy chains. Conventionally, the majority of biomassderived electricity is produced using a steam cycle process, in which biomass is burned in a boiler to generate high-pressure steam, that flows over to cause a turbine to rotate, which in response produce electricity. Although biomass is an attractive renewable source of energy, it is generally difficult to handle, transport, store, and used due to its low homogeneity, low energy density, hygroscopic, and presence of non-combustible inorganic constituents (high alkali metal content; $\mathrm{Na}, \mathrm{K}$ ), which leads to problems such as deposition sintering, agglomeration, fouling, and corrosion in the energy conversion equipment [38, 62, 63]. Bioenergy conversion technologies are used to convert biomass into useful energy. These technologies are mainly divided into two categories: thermochemical and biochemical conversion. In thermochemical conversion pathways, heat and chemical 
catalysts are used for the production of energy from biomass, while biochemical conversion pathways use biological organisms and biological catalysts for transforming biomass into energy and value-added products. In most cases, it is important to pre-treat the biomass by physical and/or chemical means, producing a secure and affordable fuel alternative that satisfies the requirements for biochemical or thermochemical conversion processes, such as fermentation, combustion, gasification, pyrolysis, and others. Pre-treatment is perhaps the most crucial step as it has a large impact on the later steps of the biomass utilization processes [63].

Driven by the necessity to find an alternative and renewable energy/fuel resources, numerous technologies have been developed and more are being developed to process oil-palm and palm-oil wastes into biofuel. Biofuel production from oil palm biomass waste involves a wide range of methods. Most of these technologies involve turning the solid biomass into liquid-gaseous mixture form and then upgrading the liquid mixture to render it suitable for combustion. As an example, Fig. 7 gives an overview of the different processing methods for solid biomass waste from oil palm industry or other related agricultural crops. Methods such as gasification, torrefaction, and pyrolysis come under the category of thermochemical energy conversion methods. Fermentation, enzymatic hydrolysis, and

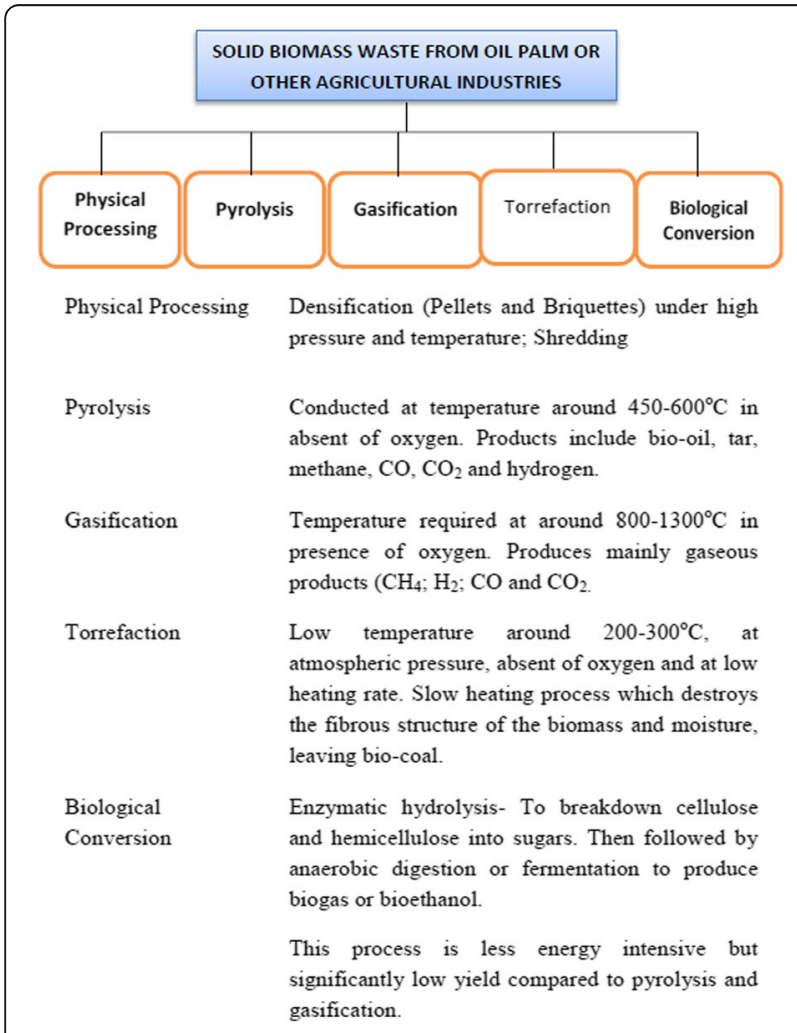

Fig. 7 General overview of processing technologies for oil palm or other agriculture crop solid biomass residues anaerobic digestion are classified under biological conversion methods whereas densification and shedding come under physical processes.

\section{Pyrolysis principles and mechanism}

Waste materials such as waste biomass, waste oil, and plastic are throughout the year all around the world. Some of these wastes are effectively collected and recovered for use as an energy source or chemical feedstock. Thermal conversion involves the use of a wide range of thermal decomposition processes such as combustion, pyrolysis, and gasification to decompose waste materials into smaller molecules that can be used as energy source or inputs for the synthesis of new materials. Combustion is a process which involves the complete oxidation of a product, gasification involves high temperatures but only partial oxidation, while pyrolysis is the thermo-chemical decomposition of hydrocarbon (or organic) materials at elevated temperatures in the absence of oxygen (typically performed by using conventional furnace heating). Table 5 shows the basic differences between the three main thermo-chemical processes of biomass.

Pyrolysis involves the simultaneous change of chemical composition and physical phase and is irreversible. Pyrolysis techniques have been developed as an alternative to treat and convert waste materials to products suitable for use as a potential energy source. It offers the potential for greater efficiencies and less pollution for the production of reactive intermediate products from biomass in comparison with other techniques. Lignocellulosic feedstocks including virgin resources and residues such as wood, coffee hulls, rice straw, waste tea, wheat straw, sewage sludge, and automotive industry wastes including auto shredder residues showed high potentials as the raw materials for the pyrolysis process [64-73]. However, the efficient decomposition of the biomass components are strongly influenced on process parameters such as reactor configuration, heat transfer, temperature of reaction, and vapor residence time [44].

Fast pyrolysis which is characterized by very high heating rate with short vapor residence time of normally less than $2 \mathrm{~s}$ and rapid cooling can be performed in an array of reactor designs (e.g., bubbling or circulating fluidized bed) to rapidly heat biomass to reaction temperature (400$600{ }^{\circ} \mathrm{C}$ ). Once biomass reaches high temperatures (i.e., $>300{ }^{\circ} \mathrm{C}$ ), it thermally depolymerizes to form small oxygenates (up to $80 \%$ yield) which are vapors in the reactor but condense to a liquid mixture (i.e., bio-oil) at room temperature $[44,74]$. Onay and coworkers [75] in a fast pyrolysis of rapeseed reported bio-oil yield of $68 \%$ at $550^{\circ}$ C. The authors [76] in a similar experiment with the same feedstock investigated the effect of temperature, heating rate, particle size, and sweep gas flow on the product yield. They concluded and reported maximum oil yield of $73 \%$ 
Table 5 The three main thermo-chemical process of biomass

\begin{tabular}{|c|c|c|c|}
\hline $\begin{array}{l}\text { Biomass conversion } \\
\text { process }\end{array}$ & Air supply & Temperature range $\left({ }^{\circ} \mathrm{C}\right)$ & Products \\
\hline Gasification & $\begin{array}{l}\text { Less than stoichiometric oxygen } \\
\text { required }\end{array}$ & $800-1000$ & $\begin{array}{l}\text { Syngas; char. } \\
\text { (The syngas produced through gasification is predominately } \\
\text { carbon monoxide, hydrogen, methane, and carbon dioxide). }\end{array}$ \\
\hline Combustion & In excess & $800-1200$ & $\begin{array}{l}\text { Flue gas and ash. } \\
\text { (Emissions of dioxins, furans). }\end{array}$ \\
\hline Pyrolysis & Absent of oxygen & $350-600$ & $\begin{array}{l}\text { Bio-oil, syngas, char. } \\
\text { (The gases and the bio-oil are from the volatile fraction of } \\
\text { biomass, while the char is mostly the fixed carbon component). }\end{array}$ \\
\hline
\end{tabular}

while char formation decreased from 27 to $14.5 \%$ with the increasing temperature within $550-600{ }^{\circ} \mathrm{C}$, particle size of $+0.6-1.25 \mathrm{~mm}$, and sweep gas flow rate of $100 \mathrm{~cm}^{3} / \mathrm{min}$. The ultimate benefit of pyrolysis is that solid biomass can be converted to a transportable liquid (bio-oil) while simultaneously increasing energy density (through deoxygenation). The products of biomass pyrolysis are shown in Fig. 8.

Depending on the thermal environment and the final temperature, pyrolysis will yield mainly biochar at low temperatures, less than $450^{\circ} \mathrm{C}$, when the heating rate is quite slow, and mainly gases at high temperatures, greater than $800{ }^{\circ} \mathrm{C}$, with rapid heating rates. At an intermediate temperature and under relatively high heating rates, the main product is bio-oil [77]. Several temperature and heating rate regimes are used, depending on the desired product slate. Characterization of biomass pyrolysis is usually by temperature and heating rate. The detailed are shown in Table 6. The fast and flash pyrolysis is thermal conversion technologies, developed to generate high liquid yields from biomass. Besides that, the diversity in the composition of biomass which is constituted by three main polymers (i.e., cellulose, hemicelluloses, and lignin) also contributes to the complexity of the final product.

Pyrolysis bio-oil; the liquid product is referred to many names including pyrolysis liquid, pyrolysis oil, tar, biocrude oil, bio-oil, bio-fuel oil, pyroligneous tar, wood

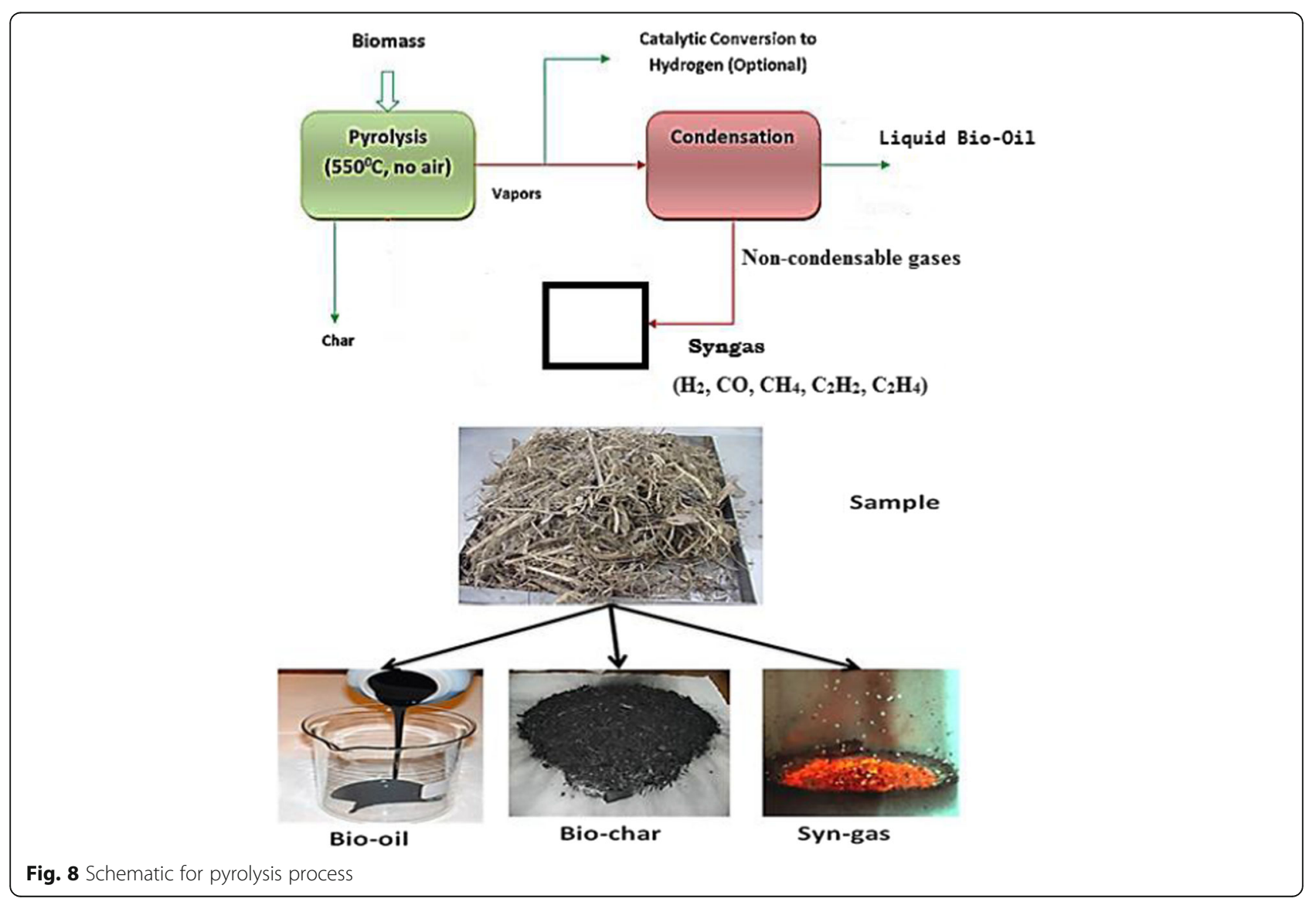


Table 6 Typical operating parameters and products for pyrolysis process, source - [78]

\begin{tabular}{|c|c|c|c|c|c|c|c|}
\hline \multirow{2}{*}{$\begin{array}{l}\text { Pyrolysis } \\
\text { process }\end{array}$} & \multirow{2}{*}{$\begin{array}{l}\text { Solid residence } \\
\text { time (s) }\end{array}$} & \multirow{2}{*}{$\begin{array}{l}\text { Heating rate } \\
(\mathrm{K} / \mathrm{s})\end{array}$} & \multirow{2}{*}{$\begin{array}{l}\text { Particle size } \\
(\mathrm{mm})\end{array}$} & \multirow[t]{2}{*}{ Temp. (K) } & \multicolumn{3}{|c|}{ Product yield (\%) } \\
\hline & & & & & Oil & Char & Gas \\
\hline Slow & $450-550$ & $0.1-1$ & $5-50$ & $550-950$ & 30 & 35 & 35 \\
\hline Fast & $0.5-10$ & 10-200 & $<1$ & $850-1250$ & 50 & 20 & 30 \\
\hline Flash & $<0.5$ & $>1000$ & $<0.2$ & 1050-1300 & 75 & 12 & 13 \\
\hline
\end{tabular}

distillates, and liquid wood. This liquid fuel can substitute for fuel oil in any static heating or electricity generation or transport application. The liquid can also be used to produce a range of specialty and commodity chemicals (for flavoring of food, phenols--adhesives for wood, fertilizer, acetic acid, sugars, and also chemicals for other industrial applications).

Biochar; being a rigid amorphous carbon matrix solid, it is dominantly consist of carbon $\sim 85 \%$ along with hydrogen and various inorganic species. Some of its applications studied by include used as solid fuel in boilers, for the production of activated carbon, in the field of nanotechnology for making nanotubes, producing hydrogen rich gas and more recently it is used as a microwave absorber in microwave-assisted reactions.

Syngas; analogous results have been reported in many other studies reviewed and reported by [78] that operated Internal Combustion (IC) engines with syngas. Sequel to all the developments, it is reported that commercial petrol and diesel engines can be easily converted to use gaseous fuel for the use of power generation, transportation, and other applications. Therefore, the syngas from biomass pyrolysis can be considered as a renewable alternative fuel for IC engines and industrial combustion routes.

Integrating microwave irradiation into pyrolysis is a novel alternative heating mechanism that has gained increasing attention in recent years. Microwave-assisted pyrolysis (MAP) has many advantages over three conventional heating, including uniform internal heating of comparatively larger particles size, instantaneous heating rates, produces fewer ashes in the liquid product as it does not require any agitations, no syngas dilution by the carrying gas, and easier technology implementation [79]. Early work on the development of MAP used batch-type process that is characterized under intermediate rate pyrolysis. A key to obtaining higher yields and quality of pyrolysis oil lies in increasing the heating rate and consequentially reducing the reaction time. In recent researches and developments, carbonaceous materials such as charcoal, activated carbon, carbon, and pyrolysis char are used as microwave absorbers to enhance the heat and mass transfers [80, 81]. A microwave pyrolysis of wood sawdust and corn stover using $\mathrm{SiC}$ as microwave absorber by [79] showed that temperature can reach up to $960^{\circ} \mathrm{C}$. Very recently, study was carried out to observe the influence of conventional slow and microwave pyrolysis on products yield. The results revealed that the use of microwave irradiation boosted the production of bio-oil. More so, the configuration of the microwave system plays a vital role [82].

The ultimate goal of this technology is to convert biomass into liquid product known as bio-oil which is considered to be a promising biofuel/bioenergy carrier and can be readily stored, transported, compete with, and eventually replace non-renewable fossil fuels. More so, the liquid can also be used to produce a range of speciality and commodity chemicals [83]. Pyrolysis offers a flexible and attractive way of converting solid biomass into an easily stored and transported liquid, which can be successfully used for the production of heat, power, and chemicals. Due to its ability to produce potentially valuable products, vigorous efforts have been made to perfect the pyrolysis process and techniques for energy recovery from waste materials, in addition to offering an alternative solution to disposal of the waste by incineration. The wide variety of pyrolysis products indicates that the products may need to be separated and purified before they can be used further; this can usually be achieved through the use of existing distillery and refinery facilities.

Different biomass constitution has consequences to the pyrolysis products which can be observed through the pyrolysis product yields and the quality of the oil. For example, the chemical structure and organic components in biomass are particularly important in the development of processes for producing derived fuels and chemicals. Numerous researchers in the literature have studied the pyrolysis of biomass on the basis of their components. In a particular study, [84] observed significant interactions between cellulose and lignin that caused a suppression of liquid product formation and an increase in solid residue yield. [85] studied the pyrolysis of Oil Palm Empty Fruit Bunch (OPEFB) in a bench scale fluidized bed reactor, where a nonhomogeneous liquid (bio-oil) was produced. In another attempt, [86] use washed OPEFB and a homogeneous liquid was produced. The bio-oil from the washed OPEFB had similar properties as wood-derived bio-oil. Pre-treatment is understood to break the internal lignin and hemicellulose bonds to increase the pore size of the biomass that can be potentially converted to useful products [87]. 
Pyrolysis is a complex non-equilibrium process where the biomass undergoes multistage decomposition resulting in large changes in specific volume. Devolatilization is a key step in thermochemical conversion and describes the process where volatile matter consisting of gas and condensates are released as the solid fuel is heated, under an inert atmosphere. The release of volatiles is due to the scission of chemical bonds in the natural polymers that comprise lignocellulosic biomass. The reaction rate, order, and product yields depend on parameters such as temperature, heating rate, pretreatment, and catalytic effects [88]. The reaction mechanism can be approximated by combining the yields from the three lignocellulosic compounds despite synergetic effects. Cellulose is the focus of much research because it is the dominant lignocellulosic compound, and therefore, cellulose decomposition is best understood. The primary cellulose reaction is described by the Waterloo-mechanism, illustrated in Fig. 9 [89].

Even though various studies have been conducted, there is still a challenge in understanding the fundamentals of the science of biomass pyrolysis and a model that can explain the chemistry undergoing. Biomass characterization such as elemental analysis, higher heating value, ash content, moisture content, and extractives content give a good idea about the source of input (solid fuel biomass) and helps to predict the output that can be obtained during pyrolysis. The studies on pyrolysis kinetics are paramount in the understanding of pyrolysis temperature range, degradation characteristics, pyrolysis process designing, and optimization of the process parameters for yield maximization. Figure 10 presents a schematic overview of the different thermal stability regimes of each of the main biomass fractions [37]. The height of the thermal stability bars corresponds to the approximate temperature level at which the thermal degradation rate of the biomass constituent under isothermal conditions and in an inert atmosphere reaches a maximum as measured by thermogravimetric analysis [90]. Thermochemical stability of the

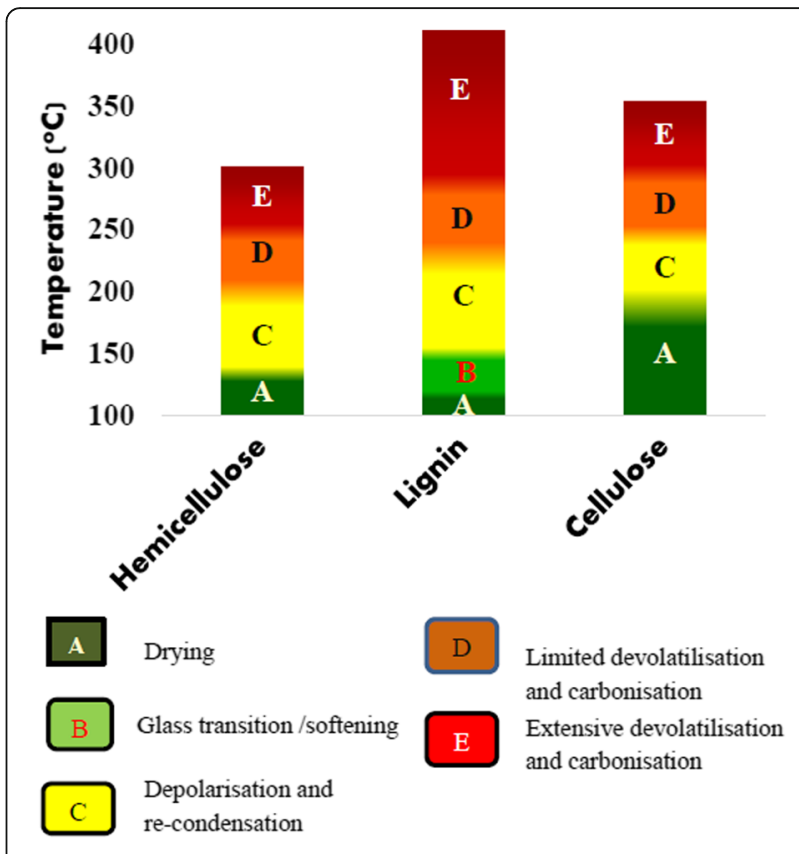

Fig. 10 Thermal stability regimes for hemicellulose, lignin, and cellulose

individual biomass constituents ranges from hemicellulose (fast degassing / decomposition from $200-300{ }^{\circ} \mathrm{C}$ ) as the least stable polymer to the more stable cellulose (fast degassing/decomposition from $300-400{ }^{\circ} \mathrm{C}$ ). Lignin exhibits intermediate thermal degradation character (gradual degassing/decomposition from $260-500{ }^{\circ} \mathrm{C}$ ).

Some important value-added chemicals that can be obtained from each of the main biomass fractions via pyrolysis are presented in Table 7 [91].

A direct conversion of the whole biomass by fast pyrolysis (the rapid thermal conversion in the absence of air) has been developed to convert biomass into high yields of bio-oil (typically up to $80 \mathrm{wt} \%$ of the dry feedstock) and remaining as gas and char. This is an efficient liquefaction of the solid biomass in a liquid product that can be regarded as a sort of molecular debris that

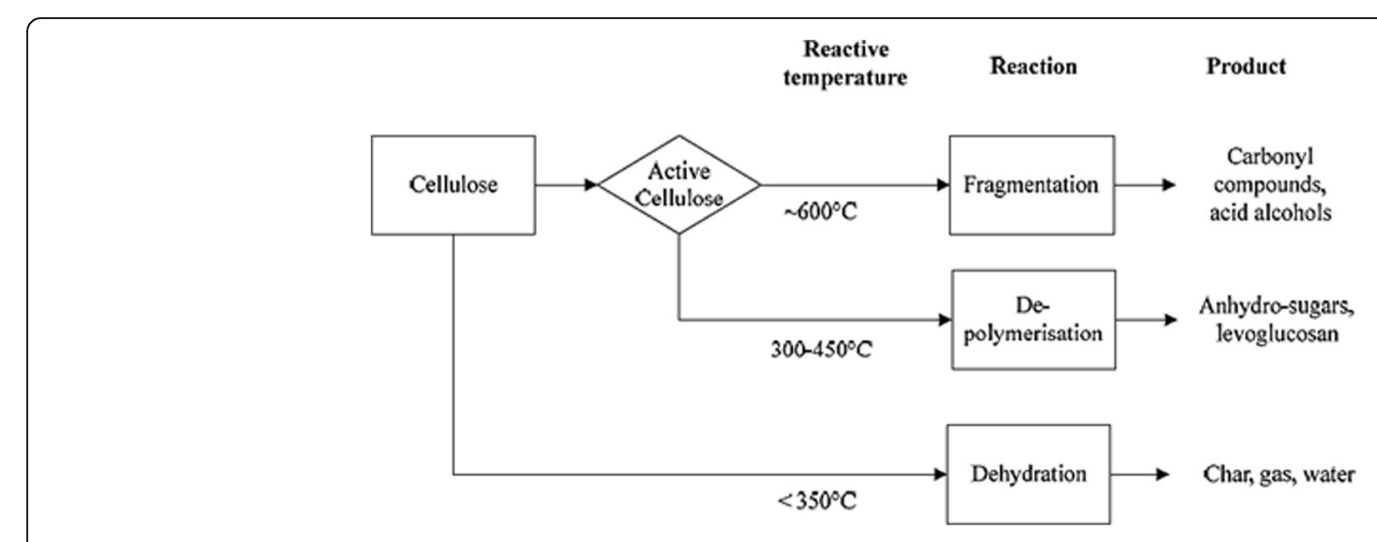

Fig. 9 Primary cellulose decomposition according to Waterloo-mechanism 
Table 7 Major chemicals from the pyrolysis of lignocellulosic biomass

\begin{tabular}{|c|c|c|}
\hline $\begin{array}{c}\text { Biomass constituent } \\
\text { (thermal degradation } \\
\text { range) }\end{array}$ & $\begin{array}{c}\text { Pyrolysis products (major value } \\
\text { added chemicals) }\end{array}$ & $\begin{array}{l}\text { Application examples of the } \\
\text { major value added chemicals }\end{array}$ \\
\hline $\begin{array}{l}\text { Hemicellulose } \\
\left(150-300^{\circ} \mathrm{C}\right)\end{array}$ & $\begin{array}{l}\text { Major - Acetic acid and furfural. } \\
\text { Others- furan, furanone, methanol, } \\
\text { other } \mathrm{C}_{1}-\mathrm{C}_{4} \text { oxygenates (e.g. } \\
\text { formaldehyde, Hydroxyl- } \\
\text { acetaldehyde, acetone, acetol, } \\
\text { lactones, etc), } \mathrm{C}_{5} \text { and } \mathrm{C}_{6}- \\
\text { anhydrosugars, humic substances. }\end{array}$ & $\begin{array}{l}\text { Bulk-chemical, vinegar (food), } \\
\text { cleansing agent, vinyl acetate, } \\
\text { acetic anhydride, esters, solvent, } \\
\text { and road deicer (as calcium } \\
\text { acetate). } \\
\text { Intermediate commodity } \\
\text { chemical, solvent, resins, } \\
\text { adhesives, precursor for } \\
\text { specialty chemicals. }\end{array}$ \\
\hline $\begin{array}{l}\text { Cellulose } \\
\left(200-400^{\circ} \mathrm{C}\right)\end{array}$ & $\begin{array}{l}\text { Major -Levoglucosan and } \\
\text { Hydroxyacetaldehyde. } \\
\\
\text { Others- } 1,6 \text { anhydro- } \beta \text {-D- } \\
\text { glucofuranose, furfural, } \\
\text { hydroxymethylfurfural, furan, } \\
\text { other } \mathrm{C}_{1}-\mathrm{C}_{4} \text { oxygenates (e.g. } \\
\text { methanol, formaldehyde, formic } \\
\text { acid, acetone, acetol, lactones, } \\
\text { etc.). }\end{array}$ & Glucose, polymers, antibiotics. \\
\hline $\begin{array}{c}\text { Lignin } \\
\left(150-600^{\circ} \mathrm{C}\right)\end{array}$ & $\begin{array}{l}\text { Major -2-methoxyphenols (e.g. } \\
\text { guaiacol), 2,6-dimethoxyphenols } \\
\text { (e.g. syringol), catechols, phenol, } \\
\text { Methanol. } \\
\text { - Others - other oxygenated }\end{array}$ & $\begin{array}{l}\text { Fine chemicals, pharmaceuticals, } \\
\text { fragrance industry, bulk- } \\
\text { chemical, wood-adhesives, } \\
\text { resins, plastics, fuel additives, } \\
\text { solvent, fuel, antifreeze, ethanol } \\
\text { denaturant, biodiesel. }\end{array}$ \\
\hline & $\begin{array}{l}\text { aromatics (e.g. coumaran), furfural, } \\
\text { acetic acid, other } \mathrm{C}_{1}-\mathrm{C}_{1} \mathrm{~S}_{\mathrm{xygenates}} \\
\text { (e.g. formaldehyde, formic acid, } \\
\text { acetone, acetol, lactones, etc). }\end{array}$ & \\
\hline $\begin{array}{l}\text { Whole biomass } \\
\left(100-600^{\circ} \mathrm{C}\right)\end{array}$ & $\begin{array}{l}\text { charcoal, } \\
\text { pyrolysis-oil } \\
\left.\text { gases (e.g. } \mathrm{CO}, \mathrm{CO}_{2}, \mathrm{CH}_{4}\right)\end{array} \quad \begin{array}{l}\mathbf{m} \\
\mathbf{a} \\
\mathbf{j} \\
\mathbf{0} \\
\mathbf{r}\end{array}$ & $\begin{array}{l}\text { Fuel, soil improver, active } \\
\text { carbon. } \\
\text { Feedstock for chemicals such as } \\
\text { organic acids. } \\
\text { Fuel }\end{array}$ \\
\hline
\end{tabular}

contains thermal degradation products from all the main biomass parts. Besides the temperature being the most dominant process variable with regard to pyrolysis, other important factors include heating rate, feed-particle size, vapor residence time, and secondary reactions. A summary of the process conditions is given in Table 8 .

Although numerous projects have been promoted, pyrolysis commercialization is progressing at a slow pace. A better knowledge of the kinetics concerning the thermal decomposition of lignocellulosic material is required. The abundant research literature on the field of biomass pyrolysis kinetics still leaves many key issues unsolved. Thermo-gravimetric analysis (TGA) is a technique used to determine changes in weight of a known quantity of sample in relation to a change in temperature. The data obtained from the TGA gives valuable information about the
Table 8 Summary of process conditions and effects

\begin{tabular}{lll}
\hline Parameter & Condition & $\begin{array}{l}\text { Optimal condition for } \\
\text { fast pyrolysis }\end{array}$ \\
\hline Reaction temperature & $500-520{ }^{\circ} \mathrm{C}$ & $\begin{array}{l}\text { Constant. } \\
\text { Vapor residence time }\end{array}$ \\
$\begin{array}{l}\text { Secondary cracking } \\
\text { Avoid }\end{array}$ & $\begin{array}{l}\text { Shorter is better. } \\
\text { Bad for product quality } \\
\text { and yield. }\end{array}$ \\
Heat transfer rate & $200{ }^{\circ} \mathrm{C} / \mathrm{s}$ & $\begin{array}{l}\text { High as possible to } \\
\text { increase liquid yield. }\end{array}$ \\
Particle size & Typically, $<2 \mathrm{~mm}$ & $\begin{array}{l}\text { Large particles limit } \\
\text { heat transfer, feeding, } \\
\text { and fluidization. }\end{array}$ \\
\hline
\end{tabular}


rate at which pyrolysis occurs. Derivative Thermogravimetry (DTG) is usually also applied to the TGA data, to determine the rate of weight loss as a function of temperature. The data generated from TGA include temperature, time, and weight changes during the pyrolysis process and these data can be used to calculate the activation energies and pre-exponential factor of different pyrolysis phases by means of a variety of mathematical models [92]. TGA can be employed only at relatively low heating rates $\left(1-50{ }^{\circ} \mathrm{C} / \mathrm{min}\right)$ because the true temperature of the samples may become unknown at high heating rates. Normally, intrinsic kinetic parameters are obtained from thermogravimetric experiments performed with low heating rates and with fine particles below $1 \mathrm{~mm}$, to produce a kinetically controlled regime [93, 94]. Intrinsic parameters are scale independent and do not include the effect of transport phenomena, which make them more reliable for scaling up and reactor design. With high heating rates and large particle sizes, thermal gradients are observed and the process becomes no longer kinetically controlled [94].

The various thermodynamic data obtained or calculated can then be used to model the pyrolysis process. Practical models that predict the evolution of specific

Table 9 Advantages, disadvantages, and bio-oil yield of different pyrolysis reactors; source [78]

\begin{tabular}{|c|c|c|c|}
\hline Reactor type & Advantages & Disadvantages & Bio-oil yield (\%) \\
\hline Fixed bed & $\begin{array}{l}\text { Simple design } \\
\text { Reliable } \\
\text { Biomass size independent }\end{array}$ & $\begin{array}{l}\text { High carbon conservation } \\
\text { Long solid residence time } \\
\text { Low ash carry over } \\
\text { Difficult to remove char }\end{array}$ & $35-50$ \\
\hline Bubbling fluidized bed & $\begin{array}{l}\text { Simple design } \\
\text { Easy operation } \\
\text { Good temperature control } \\
\text { Suitable for large scale }\end{array}$ & Small particle sizes are needed & $70-75$ \\
\hline Circulating fluidized bed & $\begin{array}{l}\text { Well-understood technology } \\
\text { Good thermal control } \\
\text { Large particle sizes can be used }\end{array}$ & $\begin{array}{l}\text { Unlikely to be suitable for large } \\
\text { Scale } \\
\text { Complex hydrodynamics } \\
\text { Char is finer }\end{array}$ & $70-75$ \\
\hline Rotating cone & $\begin{array}{l}\text { Centrifugal force moves heated sand and biomass } \\
\text { No carrier gas required } \\
\text { Less wear }\end{array}$ & $\begin{array}{l}\text { Complex process } \\
\text { Small particle sizes needed } \\
\text { Not proven yet for large scale }\end{array}$ & 65 \\
\hline Vacuum & $\begin{array}{l}\text { Produces clean oil } \\
\text { Can process larger particles of 3-5 cm } \\
\text { No carrier gas required } \\
\text { Lower temperature required } \\
\text { Easier liquid product condensation }\end{array}$ & $\begin{array}{l}\text { Slow process } \\
\text { Solid residence time is too high } \\
\text { Require large scale equipment } \\
\text { Poor heat and mass transfer rate } \\
\text { Generates more water }\end{array}$ & $35-50$ \\
\hline Ablative & $\begin{array}{l}\text { Inert gas is not required } \\
\text { Large particle sizes can be processed } \\
\text { System is more intensive } \\
\text { Moderate temperature required }\end{array}$ & $\begin{array}{l}\text { Reactor is costly } \\
\text { Low reaction rate }\end{array}$ & 70 \\
\hline Auger & $\begin{array}{l}\text { Compact } \\
\text { No carrier gas required } \\
\text { Lower process temperature }\end{array}$ & $\begin{array}{l}\text { Moving parts in hot zone } \\
\text { Heat transfer in large scale is not suitable }\end{array}$ & $30-50$ \\
\hline PyRos & $\begin{array}{l}\text { Compact and low cost } \\
\text { High heat transfer } \\
\text { Short gas residence time }\end{array}$ & $\begin{array}{l}\text { Complex design } \\
\text { Solids in the oil } \\
\text { Alkali dissolved in the oil } \\
\text { High temperature required }\end{array}$ & $70-75$ \\
\hline Plasma & $\begin{array}{l}\text { High energy density } \\
\text { High heat transfer } \\
\text { High temperature } \\
\text { Very good control }\end{array}$ & $\begin{array}{l}\text { High electrical power } \\
\text { consumption } \\
\text { High operating costs } \\
\text { Small particle sizes required }\end{array}$ & $30-40$ \\
\hline Microwave & $\begin{array}{l}\text { Efficient heat transfer } \\
\text { Exponential control } \\
\text { Compact } \\
\text { High heating rate } \\
\text { Large size biomass can be processed } \\
\text { Uniform temperature distribution } \\
\text { High temperature }\end{array}$ & High operating costs & $60-70$ \\
\hline Solar & $\begin{array}{l}\text { Use renewable energy } \\
\text { High heating rate } \\
\text { High temperature }\end{array}$ & $\begin{array}{l}\text { High costs } \\
\text { Weather dependant }\end{array}$ & $40-60$ \\
\hline
\end{tabular}


products of interest are still expected in the literature. Numerous models exist for the pyrolysis process, each with their advantages and disadvantages. They range in complexity from simple first-order models to more mathematically complex models incorporating various factors which influence the kinetics of pyrolysis. There are various methods for evaluating kinetic parameters from TGA, and the most common of them can be classified into two major types: model-fitting and model-free $[95,96]$. In the model-fitting method, different models are fit to the experimental data, and the model giving the best statistical fit is selected as the model from which the activation energy and frequency factor are evaluated. Historically, model-fitting methods were broadly used because of their ability to directly calculate the kinetic parameters from the thermogravimetric analysis results. However, these methods have several drawbacks, the most important one being their inability to uniquely select the appropriate reaction model. This led to the decline of these methods in favor of isoconversional (model-free) methods which can estimate the activation energy without evaluating the reaction model. The greatest advantages of this model are its simplicity and avoidance of errors related to selecting specific reaction models. Isoconversional method is called modelfree method because of its ability to determine the activation energy for different constant extents of conversion without considering any particular form of the reaction model. According to [97], the isoconversional analysis based on non-isothermal data was successful in correctly describing the multistep kinetics. There is still room for improvement in developing kinetic models able to describe biomass pyrolysis for a wider range of operating conditions since the kinetic parameters obtained are often suitable only for a certain range of temperatures. Improving the mechanisms in terms of predicting the product yields and composition, suitability for a wider range of biomass and operating conditions are priorities to consider in future kinetic models.

\section{Pyrolysis pyrolyzer}

The pyrolyzer is the heart of any pyrolysis process. Quite a number of different reactors have been the subject of considerable research, innovation, and development to improve the essential characteristics of high heating rates, moderate temperatures, and short vapor product residence times for liquids. Table 9 summarizes the different reactor types, specific characteristics, bio-oil yielding capacity, advantages, and limitations.

\section{Microwave-assisted pyrolysis}

There are three resulting products from the process of pyrolysis, bio-char (solid), bio-oil (liquid), and syngas (gas). The most important and the most studied product out of the three is the bio-oil. Reason for this is that biooil can be upgraded into bio-fuel. It is generally believed that the new alternative source of energy has to be in liquid form for it to be a suitable replacement for petroleum-based fuels. Generally, fast pyrolysis and flash pyrolysis are more promising alternative approaches than slow pyrolysis due to the fact that they can convert a wide range of biomass feedstock for higher bio-oil yields $[98,99]$. The raw bio-oil is obtained from pyrolysis of organic material at $350-600{ }^{\circ} \mathrm{C}$ in the absence of oxygen that is not readily available for consumption; there are many issues that negatively affect the ability for raw bio-oil to be used as a source of fuel or for value added chemical. Its complex chemical composition is one of the main reasons it cannot be utilized directly in combustion systems. Bio-oil has a low heating value of $16-18 \mathrm{Mj} / \mathrm{kg}$ because of a $15-30 \mathrm{wt} \%$ of water and 35$50 \mathrm{wt} \%$ of oxygen; its high acidity of $\mathrm{pH} 2-3$ also contribute to its undesirable qualities [100, 101]. Upgrading is used to improve the chemical and physical properties of the raw bio-oil $[102,103]$. One of the main difficulties that occur during biomass pyrolysis is the selectivity of the desired compounds in the bio-oil. Different feedstock sources lead to different ratios in the chemical composition of the bio-oil. Recently, many investigations have been geared towards improving the bio-oil yield during the pyrolysis process as well as improving the selectivity of the desired compounds in the pyrolysis oil. Catalytic microwave-assisted pyrolysis has been at the center of many recent investigations whose aim is to improve selectivity and yield of bio-oil. Microwave-assisted pyrolysis has advantages over the conventional electrical heating processes. For the conventional electrical heating, heat is transferred from high-temperature gas to the fuel particle surface through convection mechanism and it is then further transferred from the outside surface to the inside core through conduction mechanism. A temperature gradient from outside to inside of the feedstock particle is

Table 10 Comparison between microwave-assisted and electrical heating $[99,108]$

\begin{tabular}{ll}
\hline Microwave-assisted heating & Electrical heating \\
\hline Conversion of energy & Transfer of energy \\
$\begin{array}{l}\text { In-core volumetric and uniform } \\
\text { heating at molecular level }\end{array}$ & $\begin{array}{l}\text { Superficial heating via conduction, } \\
\text { convection, and radiation }\end{array}$ \\
Hot spot & No hot spot \\
Rapid & Slow \\
Higher electricity conversion efficiency & Lower electricity conversion efficiency \\
Selective & Non-selective \\
Dependent on material's properties & Less dependent \\
Precise and controlled heating & Less controllable \\
Lower thermal inertia and faster & Higher thermal inertia and slower \\
response & response \\
\hline
\end{tabular}


formed due to the poor thermal conductivity of the feedstock material [99]. For the microwave-assisted heating, microwave penetrates the feedstock particle and microwave energy is transformed into thermal energy inside the particle. Due to the heat loss effect of particle surface, thermal energy constantly accumulates inside the biomass particle and is transferred outwards. A temperature gradient from inside to outside of particle is formed, and the released volatile diffuses from the inside core to the outside surface through a lower temperature region. These different heating mechanisms make microwave-assisted heating have different characteristics as compared with conventional electrical heating (Table 10).

Traditionally, zeolite catalyst has been employed in the oil industry for its refinement [104]. With the improvement of technology, scientists have employed the same zeolite catalyst in the pyrolysis production process. Recently, Zeolite structure and chemical composition have been modified to improve its performance [105]. Apart from zeolite catalysts, metal oxides have also been used in pyrolysis processes.

The operating parameters for flash pyrolysis is a temperature of $500{ }^{\circ} \mathrm{C}$ and a residence time of about $1 \mathrm{~s}$

Table 11 Biomass feedstock properties and microwave-assisted pyrolysis

\begin{tabular}{ll}
\hline Biomass feedstock property & Remarks \\
\hline Particle size & - Smaller feedstock particle size generally improves the microwave-assisted pyrolysis process by increasing the heating \\
& rate as well as the maximal temperature [110]. \\
& The relationship between feedstock particle size and the bio-oil yield is inconsistent. Generally, too small particles \\
& of these would result in a low bio-oil yield for the microwave-assisted pyrolysis of biomass [111, 112]. \\
- The biomass particle sizes of $2-4 \mathrm{~mm}$ are better for microwave-assisted pyrolysis, and these particle sizes are larger & than the optimal particle sizes $(0.85-2 \mathrm{~mm})$ for the conventional electrical heating pyrolysis [79, 110$].$
\end{tabular}

Moisture content $\quad$ - The microwave absorbability of a biomass feedstock is described by its tangent loss (tan $\delta$ ). Water has a very good microwave absorbability, the moisture content in a biomass renders the feedstock a high temperature rising rate during the drying process [113]. With increasing temperature the moisture content evaporates, the biomass feedstock becomes less microwave absorptive, and the temperature rising rate then slows down. The tangent loss value (microwave absorbability) of a biomass feedstock would be significantly varied by reaction temperatures $[114,115]$.

- Due to the decreases in the tangent loss value, the microwave absorbability of the biomass feedstock becomes lower and lower. This makes the pyrolysis temperature can only achieve a very low value (e.g., less than $200{ }^{\circ} \mathrm{C}$ ) even if the microwave power is increased. Tangent loss materials (microwave absorbers) which can absorb microwave energy much more efficiently are used to enhance heating $[116,117]$.

Inorganics

- Ash content is another main inorganic matter in a biomass besides the abovementioned moisture content. The ash components in biomass feedstocks vary significantly from feedstock to feedstock, e.g., rice straw and wood sawdust have high contents of $\mathrm{SiO}_{2}(52.66-69.52 \%)$ and $\mathrm{K}_{2} \mathrm{O}(10.30-40.13 \%)$ while sewage sludges have low contents of $\mathrm{SiO}_{2}$ $(1.62-26.40 \%)$ and $\mathrm{K}_{2} \mathrm{O}(0.05-1.62 \%)$ [118-121].

- Generally, some ash components are good microwave absorbers and some are not. e.g., $\mathrm{Fe}_{2} \mathrm{O}_{3}$ and $\mathrm{TiO}_{2}$ ) have higher $\tan \delta$ values (0.001-0.05) whereas some ash components (e.g., $\mathrm{MgO}$ and $\mathrm{SiO}_{2}$ ) have lower $\tan \delta$ values (0.0002-0.0005) [119].

- The ash components themselves cannot be changed to form bio-oil components, the high ash content would therefore reduce the bio-oil yields. Bio-oil yields were still very low. Studied on microwave-assisted heating of three kinds of oil shales, with high ash content showed that low bio-oil yields (0-0.24 wt.\%) was obtained; which were mainly caused by the high ash contents (60.5-70.9\%) [122].

- The major organic components in biomass feedstocks are carbohydrates, proteins, and lipids. Lignocellulosic biomass is mainly composed of cellulose (23-60\%), hemicellulose (25-44\%), and lignin (12-49\%) [123]. Generally, cellulose and hemicellulose result in more bio-oil than lignin [124].

With conventional electrical heating, the decomposition temperature ranges are cellulose $\left(315-390^{\circ} \mathrm{C}\right)$, hemicellulose $\left(250-350^{\circ} \mathrm{C}\right)$, and lignin $\left(200-550^{\circ} \mathrm{C}\right)[113]$. However, with microwave-assisted pyrolysis, the lignocellulose components decomposed at lower temperature (around $100-150^{\circ} \mathrm{C}$ lower) $[115,125]$. Generally, the lignocellulosic biomass components under microwave-assisted pyrolysis would produce more bio-oil than electrical heating pyrolysis [124, 126].

- Algae biomass is rich in protein (9-30\%), lipids (30-62\%), and some carbohydrates (2-18\%). Algae biomass is usually not a good microwave absorber, even if it has high lipid content. Among carbohydrate, protein, and lipid, the good microwave absorber is lipid [127]. Microwave absorbers are generally required to obtain high temperatures for microwave-assisted pyrolysis of an algal biomass [128].

- Between microwave-assisted pyrolysis and conventional heating pyrolysis, the bio-oil yield from the microwaveassisted pyrolysis is lower $[129,130]$. However, it should be noted that generally, algal biomass produce bio-oil that has much better quality by having higher $\mathrm{H} / \mathrm{C}$ and $\mathrm{H} / \mathrm{O}$ ratios and thereby showing higher HHVs (higher heating values) [131].

- Plastics and rubbers are basically polymers with high hydrocarbons. They are also widely used in microwave-assisted pyrolysis for bio-oil production. Due to the low microwave absorbability of the plastic components (e.g., polypropylene, polystyrene, polyethylene), the plastic cannot achieve a high temperature (lower than $180^{\circ} \mathrm{C}$ ) if no microwave absorber is added but can increase significantly when microwave absorber are added [132, 133].

- Due to the high organic contents of plastics, the microwave-assisted pyrolysis of plastics would result in high bio-oil yields [132, 133].

- Compared with the plastics, rubbers are better microwave absorbers. The microwave-assisted heating of rubber can achieve a high temperature of $500{ }^{\circ} \mathrm{C}$ [134].

- The high organic contents in rubbers give high bio-oil yields for microwave-assisted pyrolysis of rubbers [132, 134]. 
and a heating rate that is greater than $\left(1000{ }^{\circ} \mathrm{C} / \mathrm{s}\right)$. The product yield composition of flash pyrolysis is $2 \%$ biochar (solid), 75\% bio-oil (liquid), and 13\% syngas (gas) [106]. Flash pyrolysis is the process with the best prospects simply because it has the highest liquid content in the products. It must also be noted that these heating rates cannot occur with only biomass inside the reaction chamber. Biomass by itself takes an extremely long time to convert into the products of biochar, bio-oil, and syngas. To facilitate this conversion process, a catalyst must be used. The addition of a catalyst to the bio-mass improves the heating rate. This allows the quantity of the bio-oil to increase. The so called catalyst mainly used in microwave pyrolysis to improve heating value are metal oxides and zeolites. The relationships among heating, bio-oil yield, and feedstock particle size, moisture content, inorganics, and organics in microwave-assisted pyrolysis will be discussed in more detail in Table 11.

Microwave-assisted pyrolysis technology has the potential for energy and cost reduction. It has been proven as a powerful tool in waste reduction, material recovery, and converting biomass and bio wastes into value-added products. However, this method has not been industrialized yet. The primary interest in either fast or flash pyrolysis is the black tarry liquid consisting of various organic compounds such as acids, alcohols, ketones, aldehydes, phenols, esters, sugars, furans, hydrocarbons, as well as large molecular oligomers and up to $20 \%$ water [107]. The bio-oil is a promising renewable energy source, which can be utilized as combustion fuels used in boiler, engines or gas turbines, and resources in chemical industries. However, the pyrolysis oil as a fuel has unfavorable properties due to its chemical composition, making it corrosive, viscose, and thermally unstable. Therefore, bio-oil must be properly upgraded to produce high-quality biofuel for use as transportation fuels. Some physical properties and characteristics of bio-oil are described in Table 12. The main advantages of pyrolysis liquid fuels include:

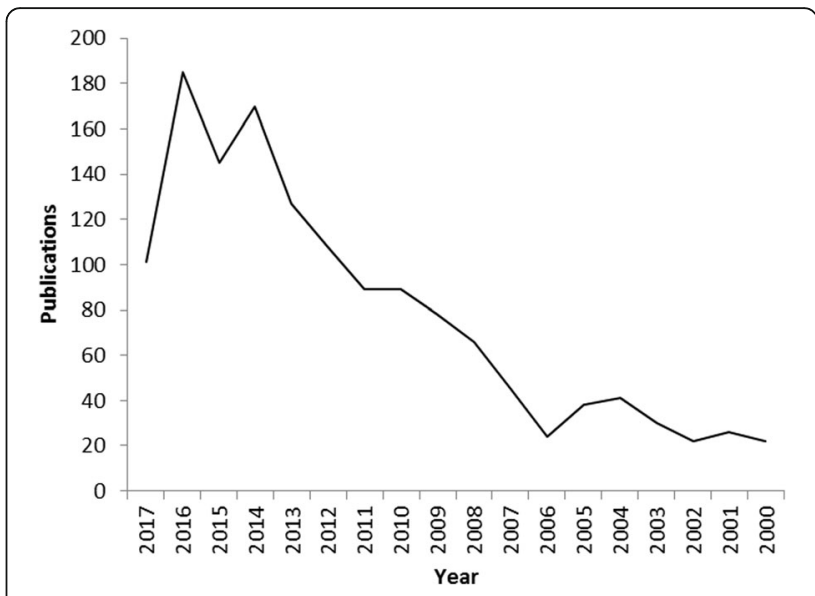

Fig. 11 Scientific publications related to microwave pyrolysis 20002017 (keywords: "microwave" AND "pyrolysis") (source: Scopus)

- $\mathrm{CO}_{2}$ balance is clearly positive in biomass fuel.

- Possibility of utilization in small-scale power generation systems as well as use in large power stations.

- Storability and transportability of liquid fuel.

- High-energy density compared to biomass gasification fuel.

- Potential of using pyrolysis liquid in existing power plants.

The cost of final products depends on many factors including the feedstock availability/cost and production technology. The cost of the pyrolysis process is the main aspect associated with the processing cost. Microwave technology is a well-established method which can be applied to thermochemical processes such as pyrolysis. The microwave-assisted pyrolysis technique offers some unique advantages, like time and energy savings, which cannot be attained with other conventional heating [108].

The microwave-assisted pyrolysis technique continues to receive considerable attention by the number of reviews

Table 12 Physical properties and characteristics of pyrolysis oil--source from [78]

\begin{tabular}{lll}
\hline Properties & Oil characteristics & Reasons \\
\hline Appearance & Dark red-brown to dark green & Micro-carbon and chemical composition in oil \\
Odor & Distinctive odor-an acid smoky smell & Lower molecular weight aldehydes and acids \\
Vensity & Pyrolysis bio-oil; $1.2 \mathrm{~kg} /$ /liter \\
& Fossil oil; $0.85 \mathrm{~kg} /$ liter & High moisture and heavy molecule contamination \\
Viscosity & Can vary as low as $25 \mathrm{cSt}$ to as high as $1000 \mathrm{cSt}$ & \\
Heating value & Significantly lower than fossil oil & Wide range of feedstock, water content, and the \\
Aging & Viscosity increase, volatility decrease, phase separation, & amount of light ends collected \\
Miscibility & and deposition of gum occur with time & High oxygen content \\
& Miscible with polar solvent but totally immiscible with & Complex structure and high pH value \\
& petroleum fuel & Polar in nature \\
\hline
\end{tabular}


Table 13 Summaries of recent studies on catalytic/microwave-assisted pyrolysis

\begin{tabular}{|c|c|c|c|}
\hline Ref. & Type of material(s) & System configuration and operation conditions & Relevant results and observations \\
\hline [110] & Prosopis juliflora (PJF) & $\begin{array}{l}\text { The experiment was performed to examine how } \\
\text { (i) microwave power, (ii) susceptor, (iii) particle } \\
\text { size, and (iv) Feed:Susceptor ratio effects on the } \\
\text { yields of bio-oil, gas, and char, composition of } \\
\text { bio-oil. By altering } 5 \text { different industrial wastes as } \\
\text { microwave susceptors, (i.e., graphite, char, } \\
\text { aluminum, silicon carbide, and fly ash) }\end{array}$ & $\begin{array}{l}\text { Maximum bio-oil was realized using fly ash of } \\
40 \mathrm{wt} \% \text { with a heating value of } 26 \mathrm{MJ} \mathrm{kg}^{-1} \text { at } \\
\text { a microwave power of } 560 \mathrm{~W} \text {, particle size of } \\
2-4 \mathrm{~mm} \text {, and Feed:Susceptor ratio of } 100: 1 \text {. The } \\
\text { bio-oil analysis showed mixtures of phenolic, } \\
\text { aromatic hydrocarbons, cyclopentanones, carboxylic } \\
\text { acids, ketones, and furan derivatives. In addition, it } \\
\text { demonstrates that the yield and quality of bio-oil } \\
\text { are dependent on key parameters such as micro } \\
\text { wave power, biomass particle size/composition, and } \\
\text { type of susceptor }\end{array}$ \\
\hline
\end{tabular}

[135] Larch

[136] Corn cob, corn stover, saw dust and rice straw

[137] Palm kernel shell

[138] Oil palm empty fruit bunch pellets

[139] Chlorella sp. strain and Nannochloropsis strain

[140] Process design--to do without susceptors

[141] Corn stalk biomass briquettes
Experiment was carried out using a fundamentally designed scalable microwave system maximize pyrolysis oil yield and quality.

The experimental materials were used without any pre-treatment and at standard microwave experimental conditions; also, $\mathrm{MgCl}_{2}$ as a catalyst

Catalytic fixed-bed and microwave pyrolysis of palm kernel shell using activated carbon (AC) and lignite char (LC) as catalysts and microwave receptors are investigated.

Experiment was carried out in a multimode microwave system with $2.45 \mathrm{GHz}$ frequency with and without the MW absorber, activated carbon.

Experiment was done in the presence of a microwave absorbent $\mathrm{SiC}$ and catalyst HZSM-5

Presented a multidisciplinary design methodology for a microwave fluidized bed system that was based on processing raw biomass without the need for added microwave susceptors.

It was carried out in a developed microwave reactor supplied with $2.45 \mathrm{GHz}$ frequency using $3 \mathrm{~kW}$ power generators.
The results suggested that with controllable sample size, the liquid product yield is comparable to conventional pyrolysis and can be achieved at an energy input around $600 \mathrm{kWh} / \mathrm{t}$. Similarly, quality of the liquid is significantly improved compared to conventional pyrolysis. This is because of the advantage the very rapid heating and quenching that can be achieved with MAP.

The pyrolysis of corn cob and corn cob plus catalyst gave the highest bio-oil yield up to 42.1 and $40 \%(\mathrm{wt})$, respectively.

Higher HHV of $22.38 \mathrm{MJ} / \mathrm{kg}$ of bio-oil from corn cob was due to the presence of ethyl ether and 2-bromo-butane with a relative proportion of 15.63 and $4.60 \%$, respectively.

In addition, GC-MS analysis of corn cob-based bio-oil showed the presence of ethyl ether, phenol, aliphatic hydrocarbons, furfural, furan derivatives, and acids in major proportions.

The authors report addition of catalyst increased the bio-oil yield, but decreased the selectivity of phenol in fixed-bed. The highest concentration of phenol in bio-oil of $64.58 \%$ (area) and total phenolics concentration of $71.24 \%$ were obtained at $500{ }^{\circ} \mathrm{C}$ using activated carbon.

The ratio of feed to absorber did influence the temperature profiles of the EFB pellets and also pyrolysis products such as bio-oil, char, and gas The highest bio-oil yield of about 21 wt.\% was obtained with 25\% MW absorber. The bio-oil consisted of phenolic compounds of about 60-70 area\% as detected by GC-MS and confirmed by FT-IR analysis.

Results for Chlorella at temperature of $550{ }^{\circ} \mathrm{C}$ without catalyst were the optimal conditions that resulted in a maximum bio-oil yield of $57 \mathrm{wt} \%$. On the other hand, optimal condition for Nannochloropsis at temperature of $500{ }^{\circ} \mathrm{C}$ with 0.5 of catalyst ratio was achieved. Resulting in a maximum bio-oil yield of $59 \mathrm{wt} . \%$.

The authors found that a minimum power density of $54 \mathrm{MW} \mathrm{m}^{-3}$ was necessary to reach temperatures of $400{ }^{\circ} \mathrm{C}$ for particles with an average size of $600 \mu \mathrm{m}$ at the minimum fluidization velocity $\left(0.38 \mathrm{~ms}^{-1}\right)$. The microwave fluidized bed system was shown to be effective in enabling pyrolysis while limiting heterogeneity and thermal runaway effects.

The highest bio-oil, biochar, and gas yield of 19.6, 41.1 , and $54.0 \%$ was achieved at different process condition. Quality wise, the biochar exhibited good heating value $(32 \mathrm{MJ} / \mathrm{kg})$ than bio-oil $(2.47 \mathrm{MJ} / \mathrm{kg})$. 
Table 13 Summaries of recent studies on catalytic/microwave-assisted pyrolysis (Continued)

[142] Rice straw, rice husk, corn stover, sugarcane bagasse, sugarcane peel, waste coffee grounds, and bamboo leaves

[143] Used cooking oil

[144] Malaysian oil palm shell, empty fruit bunch, rice husk, and coconut shell and wood sawdust

[145] Tire powders

[146] Softwood, hardwood, and herbaceous biomass

[147] Corn stover and scum
Use empirical equation to predict the various product yields. Also applied energy return on investment.

Pyrolysis was designed in order to create contact with a bed of microwave absorbents heated by microwave radiation. Different materials were used in the reaction bed, including particulate carbon, activated carbon, and mesoporous aluminosilicate

The dielectric properties were measured from room temperature to $\sim 700{ }^{\circ} \mathrm{C}$ and at six different frequencies (397, 912, 1429, 1948, 2466, and $2986 \mathrm{MHz}$ ) using a cavity perturbation method.

Experiment was carried out under standard microwave pyrolysis with special attention to the yields, and composition over time was studied

In this paper, these were processed by microwave-assisted acidolysis to produce highquality lignin.

Fast microwave-assisted catalytic co-pyrolysis for the production of bio-oil was carried out with $\mathrm{CaO}$ and HZSM-5 as the catalyst. The aim of the study was to carry out investigations on the effects of reaction temperature, $\mathrm{CaO} / \mathrm{HZSM}-5$ ratio, and corn stover/scum ratio on co-pyrolysis product fractional yields and selectivity. A constant ratio of corn stover: scum: CaO: HZSM-5 $=1: 1: 1: 1$ was used in carrying the experiment.
Solid, liquid, and gas yields were in the ranges of 18-22, 40-48, and 30-40 wt \%, respectively. The primary components of the gas product were $\mathrm{H}_{2}$ (18-25 vol\%), $\mathrm{CH}_{4}$ (6-8 vol\%), CO (51-59 vol\%), and $\mathrm{CO}_{2}(10-14$ vol\%), and the rest undetermined part was only $3-5$ vol\%. The energy return on investment of microwave pyrolysis can be approximately 3.56 , so the technique proofs can be economically feasible.

The use of particulate and activated carbon as the reaction bed provided a fast heating rate and extensive cracking capacity to pyrolyze the used oil, thus showing favorable features that could lead to short process time and less energy usage. Thus, it resulted in a production of a high yield of a biofuel product (up to 73 wt\%) in 35 min. Additionally, the biofuel showed a composition dominated by light $C_{5}-C_{20}$ aliphatic hydrocarbons with low amounts of oxygenated compounds $(\leq 11 \%)$. In particular, the oil product obtained from activated carbon bed showed low nitrogen content and was free of carboxylic acid and sulfur.

The dielectric properties recorded a fallen in the drying region $\left(24-200{ }^{\circ} \mathrm{C}\right)$ which is due to removal of moisture, and further, it decreased in the pyrolysis region $\left(200-450^{\circ} \mathrm{C}\right)$ that is due to decomposition or removal of volatile matter. Still, dielectric properties increased drastically beyond temperature $450{ }^{\circ} \mathrm{C}$. Minimum MW absorption was attained in temperature range of $300-400{ }^{\circ} \mathrm{C}$. Biochar which was formed after the pyrolysis process, showed high loss tangent as compared to the original biomass, signifying it as a suitable material for MW absorber and catalyst applications.

At the end of the pyrolysis, $43 \%$ of the solid residues, $45 \%$ of the oils, and $12 \%$ of the pyrolysis gases were obtained.

The lignin from the softwood was isolated largely intact in the solid residue after acidolysis. For example, a 10-min treatment, microwave-assisted acidolysis produced a lignin with a purity of $93 \%$ and yield of $82 \%$, superior to other conventional separation methods reported in literature.

Overall, the results showed that co-pyrolysis temperature of $550{ }^{\circ} \mathrm{C}$ gave the maximum bio-oil and aromatic yields. Mixed $\mathrm{CaO}$ and $\mathrm{HZSM}-5$ catalyst with the weight ratio of 1:4 increased the aromatic feedstock yield to 35.77 wt.\% which was $17 \%$ higher than that with HZSM-5 alone. Scum as the hydrogen donor, showed a significant synergistic effect with corn stover to promote the production of bio-oil and aromatic hydrocarbons. The maximum yield of aromatic hydrocarbons (29.3 wt.\%) were obtained when the optimal corn stover to scum ratio was 1:2. and scientific articles evident in Fig. 11. Thus, regarded as one of the best technologies in the pyrolysis process and seen to open up new markets at an increased sustainability. It offers exceptional advantages, including time and energy savings, which cannot be attained with other conventional heating methods. In table 13 , an up-to-date advances on the microwave-assisted pyrolysis method has been reviewed extensively. It provides some references that are missing in reviews to aid in quantifying the dielectric properties and nature of heat/mass transfer of input feedstocks in the design and development of microwaveassisted pyrolysis system.

\section{Conclusions}

Unquestionably, Nigeria is an "Energy Heaven" as it has almost all of the renewable and non-renewable energy 
sources in great quantity. The task now for this country is to find ways to formulate national policies to integrate these valuable resources into generation while realizing sustainable development goals. Microwave-assisted pyrolysis can be a pathway out of poverty for developing counties. It can provide new incentives for agricultural development; offer farmers an additional source of income by providing the biomass residue for bio-oil and syngas production via pyrolysis. It will also be able to help in carbon sequestration and most importantly energy security for the country. The microwave-assisted pyrolysis is reviewed in this paper as an attempt to give strong indications on what lignocellulosic biomass pyrolysis technology can offer in terms of converting waste agricultural residue, especially palm oil residue, to energy as well as helping in the reduction of overall GHG emissions for Nigeria. The overall prospect of pyrolysis technology is very optimistic because it is already a proven concept. Microwave-assisted pyrolysis appears as the most feasible of the thermo-chemical conversion techniques; capable of generating high temperatures with minimal energy. As with all new technologies, microwave pyrolysis has gained plenty of attention from researches; however, the large scale commercial plant is still not available yet. Currently, there are only few projects on continuous microwave-assisted pyrolysis which can later be scaled up into larger centralized biorefineries. It is still difficult to precisely predict the microwave-assisted pyrolysis process and results by only judging the feedstock characteristics due to the variations in feedstock characteristics. The remedy to this dilemma has been recent investigations using pretreatment techniques. Pre-treatment will bring about homogeneity to the feedstock which will allow the feedstock going into the pyrolysis process produce yield that are of similar chemical composition. Based on the analysis presented here and also that from other researchers, it is clear that there is still plenty that needs to be done in the future that will contribute to the efficiency of the overall process and its economic viability. The future works on microwave-assisted pyrolysis should focus on (i) the types of microwave absorbents since it is necessary to achieve desired temperatures, (ii) improving catalyst selectivity, (iii) optimizing reaction conditions to improve yield, (iv) study of the reaction kinetics and numerical simulation of the overall process, and $(\mathrm{v})$ the pre-treatment of the lignocellulosic biomass to achieve homogeneity.

\section{Acknowledgements}

The authors would like to thank the University Tenaga Nasional for the research facilities. Author (Bello) also like to thank the Kaduna State Government of Nigeria for the Research Scholarship. Author (Ong MY) would like to thank the Ministry of Higher Education Malaysia (MOHE) for the MyMaster scholarship.

\section{Funding}

This work was supported by the Fundamental Research Grant Scheme from the Ministry of Higher Education Malaysia (FRGS2014-2) (20150203FRGS).

\section{Authors' contributions}

SN and BS conceived and designed the study. BS, RH, and MYO performed the analysis, gathered the data, and formatted the article. BS and RH wrote the main manuscript text. All authors reviewed the manuscript. SN checked, edited, and approved the manuscript. All authors read and approved the final manuscript.

Ethics approval and consent to participate

Not applicable.

\section{Consent for publication}

Not applicable

\section{Competing interests}

The authors declare that they have no competing interests.

Received: 27 February 2017 Accepted: 7 July 2017

Published online: 01 August 2017

\section{References}

1. AfDB O, UNDP (2014) African economic outlook: global value chains and Africa's industrialisation. OECD. http://www.keepeek.com/Digital-AssetManagement/oecd/development/african-economic-outlook-2014_aeo-2014en\#page1. Accessed Aug 2016.

2. Bongaarts J (2014) United Nations, department of economic and social affairs, population division, sex differentials in childhood mortality. Popul Dev Rev 40(2):380-380

3. IEA (2014) Africa energy outlook: a focus on the energy prospects in subSaharan Africa, World Energy Outlook Special Report

4. Cervigni R, Liden R, Neumann JE, Strzepek KM (2015) Enhancing the climate resilience of Africa's infrastructure: the power and water sectors. World Bank Publications, Washington, DC

5. Emodi NV, Yusuf SD (2015) Improving electricity access in Nigeria: obstacles and the way forward. Int J Energy Econ Policy 5(1):335

6. Sambo AS (2009) Strategic developments in renewable energy in Nigeria. Int Assoc Energy Econ 16(3):15-19

7. Adeyemi AO (2013) Electricity consumption and economic growth in Nigeria. J Bus Manag Appl Econ 2(4):1-14

8. BP (2015) BP Statistical review of world energy. https://www.bp.com/ content/dam/bp/pdf/energy-economics/statistical-review-2015/bpstatistical-review-of-world-energy-2015-full-report.pdf

9. Oyedepo SO (2012) Energy and sustainable development in Nigeria: the way forward. Energy Sustain Soc 2(1):1

10. Castellano A, Kendall A, Nikomarov M, Swemmer T (2015) Brighter Africa: the growth potential of the sub-Saharan electricity sector. http://www. mckinsey.com/insights/energy_resources_materials/powering_africa

11. Dasappa S (2011) Potential of biomass energy for electricity generation in sub-Saharan Africa. Energy Sustain Dev 15(3):203-213

12. Oseni MO (2012) Households' access to electricity and energy consumption pattern in Nigeria. Renew Sust Energ Rev 16(1):990-995

13. Kooijman-van Dijk AL, Clancy J (2010) Impacts of electricity access to rural enterprises in Bolivia, Tanzania and Vietnam. Energy Sustain Dev 14(1):14-21

14. Shaaban M, Petinrin J (2014) Renewable energy potentials in Nigeria: meeting rural energy needs. Renew Sust Energ Rev 29:72-84

15. Sharif I, Mithila M (2013) Rural electrification using PV: the success story of Bangladesh. Energy Procedia 33:343-354

16. IPCC (2007) Climate Change 2007-Mitigation of Climate Change: Working Group III Contribution to the Fourth Assessment Report of the IPCC. Cambridge University Press, Cambridge

17. Edenhofer O, Pichs-Madruga R, Sokona Y, Seyboth K, Matschoss P, Kadner S, Zwickel T, Eickemeier P, Hansen G, Schlömer S (2011) IPCC special report on renewable energy sources and climate change mitigation. Prepared by Working Group III of the Intergovernmental Panel on Climate Change. Cambridge University Press, Cambridge, UK

18. DeCarolis JF, Keith DW (2006) The economics of large-scale wind power in a carbon constrained world. Energy Policy 34(4):395-410 
19. Uduma K, Arciszewski T (2010) Sustainable energy development: the key to a stable Nigeria. Sustainability 2(6):1558-1570

20. Connolly D, Lund H, Mathiesen BV, Leahy M (2010) Modelling the existing Irish energy-system to identify future energy costs and the maximum wind penetration feasible. Energy 35(5):2164-2173

21. Hiremath R, Shikha S, Ravindranath N (2007) Decentralized energy planning; modeling and application-a review. Renew Sust Energ Rev 11(5):729-752

22. Talaei A, Ahadi MS, Maghsoudy S (2014) Climate friendly technology transfer in the energy sector: a case study of Iran. Energy Policy 64:349-363

23. Wang J-J, Jing Y-Y, Zhang C-F, Zhao J-H (2009) Review on multi-criteria decision analysis aid in sustainable energy decision-making. Renew Sust Energ Rev 13(9):2263-2278

24. Saaty TL (1980) The analytic hierarchy process: planning, priority setting, resource allocation. McGraw-Hill, New York International Book Company.

25. Demirtas O (2013) Evaluating the best renewable energy technology for sustainable energy planning. Int J Energy Econ Policy 3:23

26. Theodorou S, Florides G, Tassou S (2010) The use of multiple criteria decision making methodologies for the promotion of RES through funding schemes in Cyprus, A review. Energy policy 38(12):7783-7792

27. Kaya T, Kahraman C (2010) Multicriteria renewable energy planning using an integrated fuzzy VIKOR \& AHP methodology: the case of Istanbul. Energy 35(6):2517-2527

28. Chatzimouratidis Al, Pilavachi PA (2009) Technological, economic and sustainability evaluation of power plants using the Analytic Hierarchy Process. Energy policy 37(3):778-787

29. Ajayi $\bigcirc 0$ (2010) The potential for wind energy in Nigeria. Wind Eng 34(3):303-311

30. Ohunakin OS (2010) Energy utilization and renewable energy sources in Nigeria. J Eng Appl Sci 5(2):171-177

31. Okafor $\mathrm{E}$, Joe-Uzuegbu C (2010) Challenges to development of renewable energy for electric power sector in Nigeria. Int J Acad Res 2(2):211-216

32. Adaramola M, Oyewola O (2011) Wind speed distribution and characteristics in Nigeria. ARPN J Eng Appl Sci 6(2):82-86

33. Sambo A (2005) Renewable energy for rural development: the Nigerian perspective. ISESCO Sci Technol Vision 1:12-22

34. Kurowska E, Krzysztof S (2010) Geothermal exploration in Nigeria. In: Proceedings world geothermal congress

35. Simonyan K, Fasina O (2013) Biomass resources and bioenergy potentials in Nigeria. Afr J Agric Res 8(40):4975-4989

36. Saifuddin N, Bello S, Fatihah S, Vigna K (2016) Improving electricity supply in Nigeria-potential for renewable energy from biomass. Int J Appl Eng Res 11(14):8322-8339

37. Basu P (2013) Biomass gasification, pyrolysis and torrefaction: practical design and theory. Academic press

38. Kumar P, Barrett DM, Delwiche MJ, Stroeve P (2009) Methods for Pretreatment of Lignocellulosic Biomass for Efficient Hydrolysis and Biofuel Production. Industrial \& Engineering Chemistry Research 48(8):3713-3729. doi:10.1021/ie801542g

39. White JE, Catallo WJ, Legendre BL (2011) Biomass pyrolysis kinetics: a comparative critical review with relevant agricultural residue case studies. J Anal Appl Pyrol 91(1):1-33

40. Aliyu AS, Dada JO, Adam IK (2015) Current status and future prospects of renewable energy in Nigeria. Renew Sust Energ Rev 48:336-346

41. Mohammed Y, Mustafa MW, Bashir N, Mokhtar AS (2013) Renewable energy resources for distributed power generation in Nigeria: a review of the potential. Renew Sust Energ Rev 22:257-268

42. Sambo AS, Garba B, Zarma IH, Gaji MM (2012) Electricity generation and the present challenges in the Nigerian power sector. J Energy Power Eng 6(7):1050

43. Ogwueleka T (2009) Municipal solid waste characteristics and management in Nigeria. J Environ Health Sci Eng 6(3):173-180

44. Bridgwater A, Meier D, Radlein D (1999) An overview of fast pyrolysis of biomass. Org Geochem 30(12):1479-1493

45. Hoogwijk M, Faaij A, Van Den Broek R, Berndes G, Gielen D, Turkenburg W (2003) Exploration of the ranges of the global potential of biomass for energy. Biomass Bioenergy 25(2):119-133

46. Ravindranath N, Balachandra P, Dasappa S, Rao KU (2006) Bioenergy technologies for carbon abatement. Biomass Bioenergy 30(10):826-837

47. IEA (2012) World energy outlook 2012. International Energy Agency, Paris Cedex 15, France

48. Hakala K, Kontturi M, Pahkala K (2009) Field biomass as global energy source. Agric Food Sci 18(3-4):347-365

49. Ng FY, Yew FK, Basiron Y, Sundram K (2012) A renewable future driven with Malaysian palm oil-based green technology. J Oil Palm Environ Health 2
50. Cervigni R, Valentini R, Santini M (2013) Toward climate-resilient development in Nigeria. World Bank Publications, Washington, DC.

51. Zulkifli H, Halimah M, Chan KW, Choo YM, Mohd Basri W (2010) Life cycle assessment for oil palm fresh fruit bunch production from continued land use for oil palm planted on mineral soil (part 2). J Oil Palm Res, Malaysia 22: 887-894

52. Faostat $F$ (2016) Agriculture organization of the United Nations Statistics Division (2014). Production Available in: http://faostat3.fao.org/browse/Q/ QC/S [Review date: April 2015].

53. Murphy DJ (2014) The future of oil palm as a major global crop: opportunities and challenges. J Oil Palm Res 26(1):1-24

54. Gunstone FD (2011) Supplies of vegetable oils for non-food purposes. Eur J Lipid Sci Technol 113(1):3-7

55. Feintrenie L (2014) Agro-industrial plantations in Central Africa, risks and opportunities. Biodivers Conserv 23(6):1577-1589

56. Gutiérrez-Vélez VH, DeFries R (2013) Annual multi-resolution detection of land cover conversion to oil palm in the Peruvian Amazon. Remote Sens Environ 129:154-167

57. Villela AA, D'Alembert BJ, Rosa LP, Freitas MV (2014) Status and prospects of oil palm in the Brazilian Amazon. Biomass Bioenergy 67:270-278

58. Shuit SH, Tan KT, Lee KT, Kamaruddin A (2009) Oil palm biomass as a sustainable energy source: a Malaysian case study. Energy 34(9):1225-1235

59. Abdullah N, Sulaiman F (2013) The oil palm wastes in Malaysia. Biomass Now-Sustain Growth Use 1(3):75-93

60. Kurnia JC, Jangam SV, Akhtar S, Sasmito AP, Mujumdar AS (2016) Advances in biofuel production from oil palm and palm oil processing wastes: a review. Biofuel Res J 3(1):332-346

61. Sheil D, Casson A, Meijaard E, Van Noordwjik M, Gaskell J, SunderlandGroves J, Wertz K, Kanninen M (2009) The impacts and opportunities of oil palm in Southeast Asia: what do we know and what do we need to know? vol CIFOR Occasional Paper no. 51. Center for International Forestry Research (CIFOR), Bogor, Indonesia

62. Mosier N, Wyman C, Dale B, Elander R, Lee Y, Holtzapple M, Ladisch M (2005) Features of promising technologies for pretreatment of lignocellulosic biomass. Bioresour Technol 96(6):673-686

63. Hendriks A, Zeeman G (2009) Pretreatments to enhance the digestibility of lignocellulosic biomass. Bioresour Technol 100(1):10-18

64. Dodić SN, Vasiljević TZ, Marić RM, Kosanović AJR, Dodić JM, Popov SD (2012) Possibilities of application of waste wood biomass as an energy source in Vojvodina. Renew Sust Energ Rev 16(5):2355-2360

65. Dominguez A, Menéndez J, Fernandez Y, Pis J, Nabais JV, Carrott P, Carrott MR (2007) Conventional and microwave induced pyrolysis of coffee hulls for the production of a hydrogen rich fuel gas. J Anal Appl Pyrol 79(1):128-135

66. Tsai W, Lee M, Chang Y (2006) Fast pyrolysis of rice straw, sugarcane bagasse and coconut shell in an induction-heating reactor. J Anal Appl Pyrol 76(1):230-237

67. Shie J-L, Tsou F-J, Lin K-L, Chang C-Y (2010) Bioenergy and products from thermal pyrolysis of rice straw using plasma torch. Bioresour Technol 101(2): $761-768$

68. Uzun BB, Apaydin-Varol E, Ateş F, Özbay N, Pütün AE (2010) Synthetic fuel production from tea waste: characterisation of bio-oil and bio-char. Fuel 89(1):176-184

69. Yang Z, Zhang B, Chen X, Bai Z, Zhang H (2008) Studies on pyrolysis of wheat straw residues from ethanol production by solid-state fermentation. $J$ Anal Appl Pyrol 81(2):243-246

70. De Wild P, Huijgen W, Heeres H (2012) Pyrolysis of wheat straw-derived organosolv lignin. J Anal Appl Pyrol 93:95-103

71. Fonts I, Gea G, Azuara M, Ábrego J, Arauzo J (2012) Sewage sludge pyrolysis for liquid production: a review. Renew Sust Energ Rev 16(5):2781-2805

72. Nourreddine M (2007) Recycling of auto shredder residue. J Hazard Mater 139(3):481-490

73. Domínguez A, Fernández Y, Fidalgo B, Pis J, Menéndez J (2008) Bio-syngas production with low concentrations of $\mathrm{CO}_{2}$ and $\mathrm{CH}_{4}$ from microwaveinduced pyrolysis of wet and dried sewage sludge. Chemosphere 70(3): 397-403

74. Mettler MS, Vlachos DG, Dauenhauer PJ (2012) Top ten fundamental challenges of biomass pyrolysis for biofuels. Energy Environ Sci 5(7):7797-7809

75. Onay Ö, Beis S, Koçkar ÖM (2001) Fast pyrolysis of rape seed in a well-swept fixed-bed reactor. J Anal Appl Pyrol 58:995-1007

76. Onay O, Kockar OM (2003) Slow, fast and flash pyrolysis of rapeseed. Renew Energy 28(15):2417-2433 
77. Goyal H, Seal D, Saxena R (2008) Bio-fuels from thermochemical conversion of renewable resources: a review. Renew Sust Energ Rev 12(2):504-517

78. Jahirul MI, Rasul MG, Chowdhury AA, Ashwath N (2012) Biofuels production through biomass pyrolysis-a technological review. Energies 5(12):4952-5001

79. Borges FC, Du Z, Xie Q, Trierweiler JO, Cheng Y, Wan Y, Liu Y, Zhu R, Lin X, Chen $P$ (2014) Fast microwave assisted pyrolysis of biomass using microwave absorbent. Bioresour Technol 156:267-274

80. Salema AA, Ani FN Heating characteristics of biomass and carbonaceous materials under microwave radiation. In: Clean Energy and Technology (CET), 2011 IEEE First Conference on, 2011. IEEE, pp 72-77

81. Salema AA, Ani FN (2011) Microwave induced pyrolysis of oil palm biomass. Bioresour Technol 102(3):3388-3395

82. Halim SA, Swithenbank J (2016) Characterisation of Malaysian wood pellets and rubberwood using slow pyrolysis and microwave technology. J Anal Appl Pyrol 122:64-75

83. Stefanidis SD, Kalogiannis KG, Iliopoulou EF, Michailof CM, Pilavachi PA, Lappas AA (2014) A study of lignocellulosic biomass pyrolysis via the pyrolysis of cellulose, hemicellulose and lignin. J Anal Appl Pyrol 105:143-150

84. Worasuwannarak N, Sonobe T, Tanthapanichakoon W (2007) Pyrolysis behaviors of rice straw, rice husk, and corncob by TG-MS technique. J Anal Appl Pyrol 78(2):265-271

85. Abdullah N, Bridgwater A (2006) Pyrolysis liquid derived from oil palm empty fruit bunches. J Phys Sci 17(2):117-129

86. Abdullah N, Gerhauser H (2008) Bio-oil derived from empty fruit bunches. Fuel 87(12):2606-2613

87. Tan L, Yu Y, Li X, Zhao J, Qu Y, Choo YM, Loh SK (2013) Pretreatment of empty fruit bunch from oil palm for fuel ethanol production and proposed biorefinery process. Bioresour Technol 135:275-282

88. Bridgwater A, Toft A, Brammer J (2002) A techno-economic comparison of power production by biomass fast pyrolysis with gasification and combustion. Renew Sust Energ Rev 6(3):181-246

89. Van de Velden M, Baeyens J, Brems A, Janssens B, Dewil R (2010) Fundamentals, kinetics and endothermicity of the biomass pyrolysis reaction. Renewable energy 35(1):232-242

90. Yang H, Yan R, Chen H, Zheng C, Lee DH, Liang DT (2006) In-depth investigation of biomass pyrolysis based on three major components: hemicellulose, cellulose and lignin. Energy Fuels 20(1):388-393

91. Bridgwater A, Hofbauer H, Van Loo S (2009) Thermal biomass conversion. CPL Press

92. Mohan D, Pittman CU, Steele PH (2006) Pyrolysis of Wood/Biomass for Biooil: A Critical Review. Energy \& Fuels 20 (3):848-889. doi:10.1021/ef0502397

93. Blondeau J, Jeanmart H (2012) Biomass pyrolysis at high temperatures: prediction of gaseous species yields from an anisotropic particle. Biomass Bioenergy 41:107-121

94. Burnham AK, Zhou X, Broadbelt LJ (2015) Critical review of the global chemical kinetics of cellulose thermal decomposition. Energy Fuels 29(5): 2906-2918

95. Jiang G, Nowakowski DJ, Bridgwater AV (2010) A systematic study of the kinetics of lignin pyrolysis. Thermochimica Acta 498(1):61-66

96. Sbirrazzuoli N, Vincent L, Mija A, Guigo N (2009) Integral, differential and advanced isoconversional methods: complex mechanisms and isothermal predicted conversion-time curves. Chemometr Intell Lab Syst 96(2):219-226

97. Budrugeac P (2002) Differential non-linear isoconversional procedure for evaluating the activation energy of non-isothermal reactions. J Therm Anal Calorim 68(1):131-139

98. Papari S, Hawboldt K (2015) A review on the pyrolysis of woody biomass to bio-oil: focus on kinetic models. Renew Sust Energ Rev 52:1580-1595

99. Chen P, Xie Q, Addy M, Zhou W, Liu Y, Wang Y, Cheng Y, Li K, Ruan R (2016) Utilization of municipal solid and liquid wastes for bioenergy and bioproducts production. Bioresour Technol 215:163-172

100. Duan P, Savage PE (2011) Upgrading of crude algal bio-oil in supercritical water. Bioresour Technol 102(2):1899-1906

101. Peterson AA, Vogel F, Lachance RP, Fröling M, Antal MJ Jr, Tester JW (2008) Thermochemical biofuel production in hydrothermal media: a review of sub-and supercritical water technologies. Energy Environ Sci 1(1):32-65

102. Gunawan R, Li X, Lievens C, Gholizadeh M, Chaiwat W, Hu X, Mourant D, Bromly J, Li C-Z (2013) Upgrading of bio-oil into advanced biofuels and chemicals. Part I. Transformation of GC-detectable light species during the hydrotreatment of bio-oil using Pd/C catalyst. Fuel 111:709-717

103. Zhang $X$, Zhang Q, Wang T, Li B, Xu Y, Ma L (2016) Efficient upgrading process for production of low quality fuel from bio-oil. Fuel 179:312-321
104. Wang L, Lei H, Ren S, Bu Q, Liang J, Wei Y, Liu Y, Lee G-SJ, Chen S, Tang J (2012) Aromatics and phenols from catalytic pyrolysis of Douglas fir pellets in microwave with ZSM-5 as a catalyst. J Anal Appl Pyrol 98:194-200

105. Zhang B, Zhong Z, Chen P, Ruan R (2015) Microwave-assisted catalytic fast pyrolysis of biomass for bio-oil production using chemical vapor deposition modified HZSM-5 catalyst. Bioresour Technol 197:79-84

106. Marcilla A, Catalá L, García-Quesada JC, Valdés F, Hernández M (2013) A review of thermochemical conversion of microalgae. Renew Sust Energ Rev 27:11-19

107. Zhang Q, Chang J, Wang T, Xu Y (2007) Review of biomass pyrolysis oil properties and upgrading research. Energy Convers Manag 48(1):87-92

108. Motasemi F, Afzal MT (2013) A review on the microwave-assisted pyrolysis technique. Renew Sust Energ Rev 28:317-330

109. NESP (2015) The Nigerian energy sector--an overview with a special emphasis on renewable energy, energy efficiency and rural electrification. https://www.giz.de/en/downloads/giz2015-en-nigerian-energy-sector.pdf

110. Suriapparao DV, Pradeep N, Vinu R (2015) Bio-oil production from Prosopis juliflora via microwave pyrolysis. Energy Fuels 29(4):2571-2581

111. Shang H, Lu R-R, Shang L, Zhang W-H (2015) Effect of additives on the microwave-assisted pyrolysis of sawdust. Fuel Process Technol 131:167-174

112. Kan T, Strezov V, Evans TJ (2016) Lignocellulosic biomass pyrolysis: a review of product properties and effects of pyrolysis parameters. Renew Sust Energ Rev 57:1126-1140

113. Omar R, Idris A, Yunus R, Khalid K, Isma MA (2011) Characterization of empty fruit bunch for microwave-assisted pyrolysis. Fuel 90(4):1536-1544

114. Motasemi F, Ani FN (2012) A review on microwave-assisted production of biodiesel. Renew Sust Energ Rev 16(7):4719-4733

115. Budarin VL, Shuttleworth PS, Farmer TJ, Gronnow MJ, Pfaltzgraff L, Macquarrie DJ, Clark JH (2015) The potential of microwave technology for the recovery, synthesis and manufacturing of chemicals from bio-wastes. Catalysis Today 239:80-89

116. Mamaeva A, Tahmasebi A, Tian L, Yu J (2016) Microwave-assisted catalytic pyrolysis of lignocellulosic biomass for production of phenolic-rich bio-oil. Bioresour Technol 211:382-389

117. Mohamed BA, Kim CS, Ellis N, Bi X (2016) Microwave-assisted catalytic pyrolysis of switchgrass for improving bio-oil and biochar properties. Bioresour Technol 201:121-132

118. Liu H, Ma X, Li L, Hu Z, Guo P, Jiang Y (2014) The catalytic pyrolysis of food waste by microwave heating. Bioresour Technol 166:45-50

119. Li L, Ma X, Xu Q, Hu Z (2013) Influence of microwave power, metal oxides and metal salts on the pyrolysis of algae. Bioresour Technol 142:469-474

120. Yu Y, Yu J, Sun B, Yan Z (2014) Influence of catalyst types on the microwave-induced pyrolysis of sewage sludge. J Anal Appl Pyrol 106:86-91

121. Budarin VL, Clark JH, Lanigan BA, Shuttleworth P, Breeden SW, Wilson AJ, Macquarrie DJ, Milkowski K, Jones J, Bridgeman T (2009) The preparation of high-grade bio-oils through the controlled, low temperature microwave activation of wheat straw. Bioresour Technol 100(23):6064-6068

122. Hascakir B, Akin S (2009) Recovery of Turkish oil shales by electromagnetic heating and determination of the dielectric properties of oil shales by an analytical method. Energy Fuels 24(1):503-509

123. Du Z, Hu B, Ma X, Cheng Y, Liu Y, Lin X, Wan Y, Lei H, Chen P, Ruan R (2013) Catalytic pyrolysis of microalgae and their three major components: carbohydrates, proteins, and lipids. Bioresour Technol 130:777-782

124. Farag S, Fu D, Jessop PG, Chaouki J (2014) Detailed compositional analysis and structural investigation of a bio-oil from microwave pyrolysis of kraft lignin. J Anal Appl Pyrol 109:249-257

125. Mašek $O$, Budarin $V$, Gronnow $M$, Crombie $K$, Brownsort $P$, Fitzpatrick $E$, Hurst $P$ (2013) Microwave and slow pyrolysis biochar — comparison of physical and functional properties. J Anal Appl Pyrol 100:41-48

126. Suriapparao DV, Vinu R (2015) Bio-oil production via catalytic microwave pyrolysis of model municipal solid waste component mixtures. RSC Advances 5(71):57619-57631

127. Patil $P$, Reddy H, Muppaneni T, Ponnusamy S, Sun Y, Dailey P, Cooke P, Patil U, Deng S (2013) Optimization of microwave-enhanced methanolysis of algal biomass to biodiesel under temperature controlled conditions. Bioresour Technol 137:278-285

128. Wang N, Tahmasebi A, Yu J, Xu J, Huang F, Mamaeva A (2015) A comparative study of microwave-induced pyrolysis of lignocellulosic and algal biomass. Bioresour Technol 190:89-96

129. Beneroso D, Bermúdez J, Arenillas A, Menéndez J (2013) Microwave pyrolysis of microalgae for high syngas production. Bioresour Technol 144:240-246 
130. Bermúdez JM, Francavilla $M$, Calvo EG, Arenillas $A$, Franchi M, Menéndez JA, Luque R (2014) Microwave-induced low temperature pyrolysis of macroalgae for unprecedented hydrogen-enriched syngas production. RSC Advances 4(72):38144-38151

131. Ferrera-Lorenzo N, Fuente E, Bermúdez J, Suárez-Ruiz I, Ruiz B (2014) Conventional and microwave pyrolysis of a macroalgae waste from the Agar-Agar industry. Prospects for bio-fuel production. Bioresour Techno 151:199-206

132. Undri A, Rosi L, Frediani M, Frediani P (2014) Microwave assisted pyrolysis of corn derived plastic bags. J Anal Appl Pyrol 108:86-97

133. Bartoli M, Rosi L, Frediani M, Undri A, Frediani P (2015) Depolymerization of polystyrene at reduced pressure through a microwave assisted pyrolysis. J Anal Appl Pyrol 113:281-287

134. Yang ALC, Ani FN (2016) Controlled microwave-induced pyrolysis of waste rubber tires. Int J Technol 7(2):314-322

135. Robinson J, Dodds C, Stavrinides A, Kingman S, Katrib J, Wu Z, Medrano J, Overend R (2015) Microwave pyrolysis of biomass: control of process parameters for high pyrolysis oil yields and enhanced oil quality. Energy Fuels 29(3):1701-1709

136. Ravikumar C, Kumar PS, Subhashni S, Tejaswini P, Varshini V (2017) Microwave assisted fast pyrolysis of corn cob, corn stover, saw dust and rice straw: experimental investigation on bio-oil yield and high heating values. Sustain Mater Technol 11:19-27

137. Omoriyekomwan JE, Tahmasebi A, Yu J (2016) Production of phenol-rich bio-oil during catalytic fixed-bed and microwave pyrolysis of palm kernel shell. Bioresour Technol 207:188-196

138. Salema AA, Ani FN (2012) Pyrolysis of oil palm empty fruit bunch biomass pellets using multimode microwave irradiation. Bioresour Technol 125: 102-107

139. Borges FC, Xie Q, Min M, Muniz LAR, Farenzena M, Trierweiler JO, Chen P, Ruan R (2014) Fast microwave-assisted pyrolysis of microalgae using microwave absorbent and HZSM-5 catalyst. Bioresour Technol 166:518-526

140. Adam M, Beneroso D, Katrib J, Kingman S, Robinson JP (2017) Microwave fluidized bed for biomass pyrolysis. Part l: Process design. Biofuels, Bioprod. Bioref 11:601-612. doi:10.1002/bbb.1780

141. Salema AA, Afzal MT, Bennamoun L (2017) Pyrolysis of corn stalk biomass briquettes in a scaled-up microwave technology. Bioresour Technol 233: 353-362

142. Lo S-L, Huang Y-F, Chiueh P-T, Kuan W-H (2017) Microwave pyrolysis of lignocellulosic biomass. Energy Procedia 105:41-46

143. Lam SS, Mahari WAW, Jusoh A, Chong CT, Lee CL, Chase HA (2017) Pyrolysis using microwave absorbents as reaction bed: an improved approach to transform used frying oil into biofuel product with desirable properties. J Clean Prod 147:263-272

144. Salema AA, Ani FN, Mouris J, Hutcheon R (2017) Microwave dielectric properties of Malaysian palm oil and agricultural industrial biomass and biochar during pyrolysis process. Fuel Process Technol 166:164-173

145. Song Z, Yang Y, Zhao X, Sun J, Wang W, Mao Y, Ma C (2017) Microwave pyrolysis of tire powders: evolution of yields and composition of products. J Anal Appl Pyrol 123:152-159

146. Zhou L, Santomauro F, Fan J, Macquarrie D, Clark J, Chuck CJ, Budarin V (2017) Fast microwave-assisted acidolysis: a new biorefinery approach for the zero-waste utilisation of lignocellulosic biomass to produce high quality lignin and fermentable saccharides. Faraday Discussions. doi:10.1039/ C7FD00102A

147. Liu S, Xie Q, Zhang B, Cheng Y, Liu Y, Chen P, Ruan R (2016) Fast microwave-assisted catalytic co-pyrolysis of corn stover and scum for bio-oil production with $\mathrm{CaO}$ and HZSM-5 as the catalyst. Bioresour Technol 204: 164-170

\section{Submit your manuscript to a SpringerOpen ${ }^{\circ}$ journal and benefit from:}

- Convenient online submission

- Rigorous peer review

- Open access: articles freely available online

- High visibility within the field

- Retaining the copyright to your article

Submit your next manuscript at $\gg$ springeropen.com 